九州大学学術情報リポジトリ

Kyushu University Institutional Repository

Litho- and biostratigraphy of the 0ligoceneMiocene Nichinan Group in the Miyazaki Prefecture, Kyushu

Nishi, Horoshi

Faculty of Science, Kyushu University

https://doi.org/10.5109/1546318

出版情報：九州大學理學部紀要：Series D, Geology. 25 (3)，pp.289-317，1985-02-25. Faculty of Science, Kyushu University バージョン：

権利関係 : 
Mem. Fac. Sci., Kyushu Univ., Ser. D, Geol., Vol. XXV, No. 3, pp. 289-317, text-figs. 1-11, plates $38-40$, February 25,1985

\title{
Litho- and biostratigraphy of the Oligocene-Miocene Nichinan Group in the Miyazaki Prefecture, Kyushu
}

\author{
Hiroshi NISHI
}

\begin{abstract}
This paper describes the litho- and biostratigraphy of the OligoceneMiocene Nichinan Group in Nango-cho, Minaminaka-gun, Miyazaki Prefecture, which belongs to the southern part of the Shimanto Belt in the Outer Zone of Southwest Japan.

The Nichinan Group of the area is lithologically divided into the Ichiki, Nango, and Takigahirayama Formations in ascending order. The Ichiki Formation ( $170 \mathrm{~m}$ thick) is composed mainly of massive mudstone with thinbedded alternating beds of sandstone and mudstone in the uppermost part. The Nango Formation ( $400 \mathrm{~m}$ thick) consists of two cyclic units characterized by a thinning- and fining-upward sequence that begins with conglomerate or pebbly sandstone and passes upward into alternating beds of sandstone and mudstone, and ends with mudstone. The conglomerate beds have distinct scoured bases, contain angular fragments of mudstone in their lower part, and merge rapidly upward and laterally into coarse-grained sandstones which commonly show dish and convolute structures. These features imply that the basal part of cyclic deposition includes channel-fill debris flow deposits. The Takigahirayama Formation $(780 \mathrm{~m}$ thick) is subdivided into the Lower and Upper Subformations. The Lower Subformation $(460 \mathrm{~m})$ is made up mostly of 0.5 to $2 \mathrm{~m}$ thick-bedded sandstone with parallel to ripple-cross lamination in the lower, alternating beds of sandstone and mudstone in the middle, and mudstone in the upper. The Upper Subformation $(320 \mathrm{~m})$ consists of alternating beds of sandstone and mudstone, massive sandstone containing small mudstone fragments, alternating beds of sandstone and mudstone, and mudstone in the ascending order. Thus, this formation is also characterized by two cyclic sequences. The lithologic sequence and sedimentary features suggest that the Nichinan Group of the area can be referred to as submarine fan, probably middle to lower fan, deposits.

Three assemblage zones of planktonic Foraminifera were recognized within the Nichinan Group of the area. They are the Zones of Globorotalia (Turborotalia) opima opima, the Globigerina angulisuturalis, and the Globorotalia (Turborotalia) kugleri in ascending order. The Ichiki Formation and the lower part of the Nango Formation belong to the $G$. (T.) opima opima Zone, the upper part of the Nango Formation and the lower part of the Takigahirayama Formation to the G. angulisuturalis Zone, and the middle and upper part of the Takigahirayama Formation to the G. (T.) kugleri Zone. These zones represent BLow's P. 21 (Late Oligocene), P. 22 (Latest Oligocene), and N. 4 (Earliest Miocene), respectively. Therefore, the Oligocene-Miocene boundary is placed in the middle of the Takigahiraya Formation. This is the first confirmation of the Oligocene-Miocene boundary by microfossils in Japan.
\end{abstract}

Manuscript received September $30,1984$. 


\section{Introduction}

Although Tertiary sedimentary rocks are widely distributed in many areas of Japan, apparently continuous marine sequences ranging from the Paleogene to the Neogene are known to occur only in the Shimanto Terrane in the Outer Zone of Southwest Japan. However, the Paleogene and lower Miocene strata of this terrane are structurally complex, and despite many previous investigations, nowhere biostratigraphic zonation or divisions have so far been established. Fortunately I was successful to establish the biostratigraphic divisions based on planktonic Foraminifera of the sequence from the Upper Oligocene to the Lower Miocene of the Nichinan Group in the Nichinan Mountains (Wanizuka Mountains) of Southern Kyushu. This paper gives descriptions of the litho- and bio-stratigraphy of the Nichinan Group and discussions about the depositional environments and paleobathymetric setting of the group.

\section{Geologic Setting and Previous Work}

The Nichinan Mountains lies in the southernmost part of Miyazaki Prefecture, southern Kyushu, and includes the cities of Nichinan and Kushima near the coast. This area geotectonically belongs to the southern belt of the Shimanto Terrane, and consists of structurally complex Paleogene and lower Miocene strata, named the Nichinan Group by KuRoda and Matsumoto (1942), in the main part and the unconformably overlying and gently east-dipping upper Miocene-Pliocene Miyazaki Group in the eastern margin. Omitting some early geologic notations, the first important paper on the stratigraphy and geologic structures of the Nichinan Group was by SHuto (1963). He divided the Nichinan Group into the Nichinan Subgroup including the Ichiki, Nango and Takigahirayama Formations and the Sakatani Subgroup, and assigned the group to early Oligocene (Lattorfian) to early Miocene (Aquitanian) in age on the basis of molluscan and foraminiferal fossils. He listed the fossil content of each formation collectively, but did not indicate elements necessary for biostratigraphic divisions or zonation such as stratigraphic positions and vertical ranges of occurrence of the fossils, specific assemblages and zone-boundaries in relation to the stratigraphic sequence.

Geologic work during recent years (KANMERA and SASAKI, 1977; KANMERA et al., 1983; SAKAI et al., 1984) revealed that at least the southern part of the Nichinan Mountains is comprised of a large-scale gravity-slide complex or olistostromes containing blocks of sandstone, alternating beds of sandstone and mudstone, and massive siltstone and mudstone of various sizes up to several $\mathrm{km}$ thick in a sheared and intensely contorted muddy matrix, which also contains smaller clasts of sandstone and mudstone. Similar view was also presented by NAKaGaWA et al. (1983) and Kato et al. (1984). The blocks are of various lithofacies ranging from a shallow water facies containing thickshelled molluses such as Glycymeris and Venercaldia to a deep water one consisting mainly of turbidites. One of large blocks is the Nango Blocks which lies in the southern part of Nango-cho including the villages of Meotoura and Ichiki, 
and which is as large as about $3 \mathrm{~km}$ by $4 \mathrm{~km}$. It seems to be surrounded by a chaotic complex, but the block itself shows a simple geologic structure dipping north with an overturned syncline (Nango Syncline) in the northern part of the block (Fig. 1). Therefore, the stratigraphy of the rocks within this block can be studied in detail, although the top and bottom of the sequence cannot be determined. KANMERA et al. (1983) mapped the area of the Nango Block and its environs, and gave brief descriptions of the lithostratigraphy. However, paleontological studies of the contained microfossils and biostratigraphic zonation in addition to the detailed descriptions of the lithologic sequence have been left to my work. The biostratigraphic sequence of the Nichinan Group herein established would be the stratotype of marine beds of Oligocene to Lower Miocene ages in Japan.

Establishment of the litho- and bio-stratigraphy of the Nichinan Group within and among the blocks is essentially important not only to know the provenance and original framework of the chaotic slide complex of the Nichinan Mountains, but also to elucidate the sedimentary and tectonic relationships to the Upper Eocene to Lower Oligocene Hyuga Group of the Hyuga Mountains which is notherly adjacent to the Nichinan Mountains. The Hyuga Group is characterized by alternating beds of flysch facies and structurally by southerly verging imbricate structures, and is considered to be accretionary prisms (SAKAI and KANMERA, 1981; SAKAI et al., 1984). On the contrary, the Nichinan Group here in dealt with is characterized by thick cyclic sequences, and shows a striking contrast in lithofacies and geologic structure to the Hyuga Group.

\section{Lithostratigraphy of the Nichinan Group}

The Nichinan Group of the investigated area consists of several, 140 to $450 \mathrm{~m}$ thick, mostly fining-upward cyclic sequences ranging from thick-bedded sandstone with some interbeds of shale-pebble conglomerate through thinly interbedded sandstone and shale to massive mudstone. The base and top of the group cannot be known because of lack of exposures, but the overall thickness of the exposed sequences attains approximately $1300 \mathrm{~m}$. The group is lithostratigraphically divided into the Ichiki, Nango, and Takigahirayama Formations in ascending order. This group abundantly yields Foraminifera and Radiolaria from mudstone at many levels, but no megafossils were detected at all.

\section{A. Lithologic Feature and Stratigraphic Sequence}

\section{Ichiki Formation}

Type locality: Along the Heta Coast

Thickness: $170 \mathrm{~m}+$

The Ichiki Formation is narrowly exposed along the southern coast of the study area (Fig. 1). It is composed of darkgray massive mudstone with occasional thin sandy layers in the main part ( $150 \mathrm{~m}$ thick) and rhythmically alternating thin beds of sandstone and mudstone in the uppermost part $(15 \mathrm{~m})$. The latter is transitional with the former and exhibits a sandstone/mudstone ratio of 1.3 to 1.5 (Figs. 1 and 9 ). 


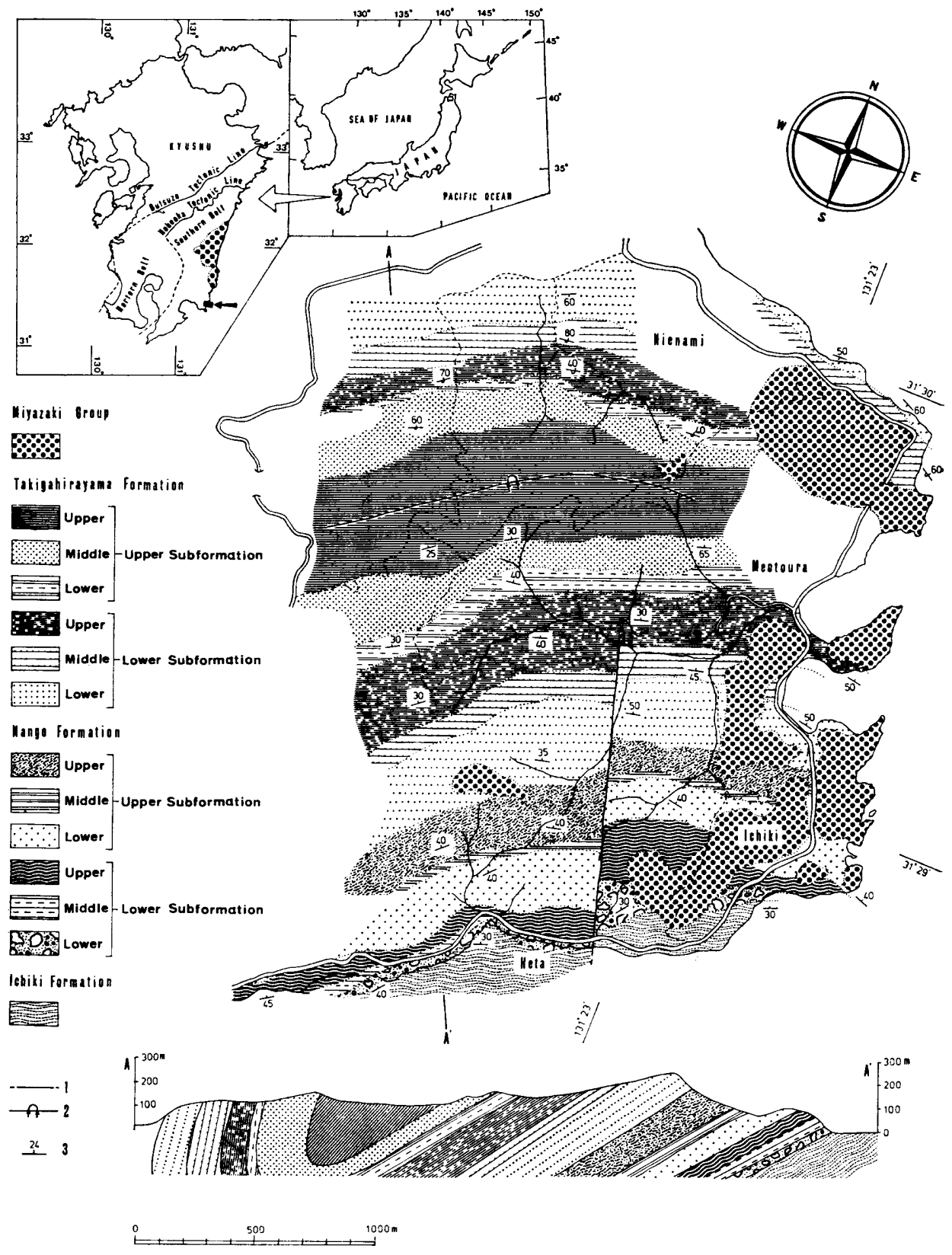

Fig. 1. Geological map and cross section of Nango area in Nichinan Mountains. Index maps are shown in insets.

1, fault; 2, axis of Nango Syncline; 3, strike and dip of beds. 


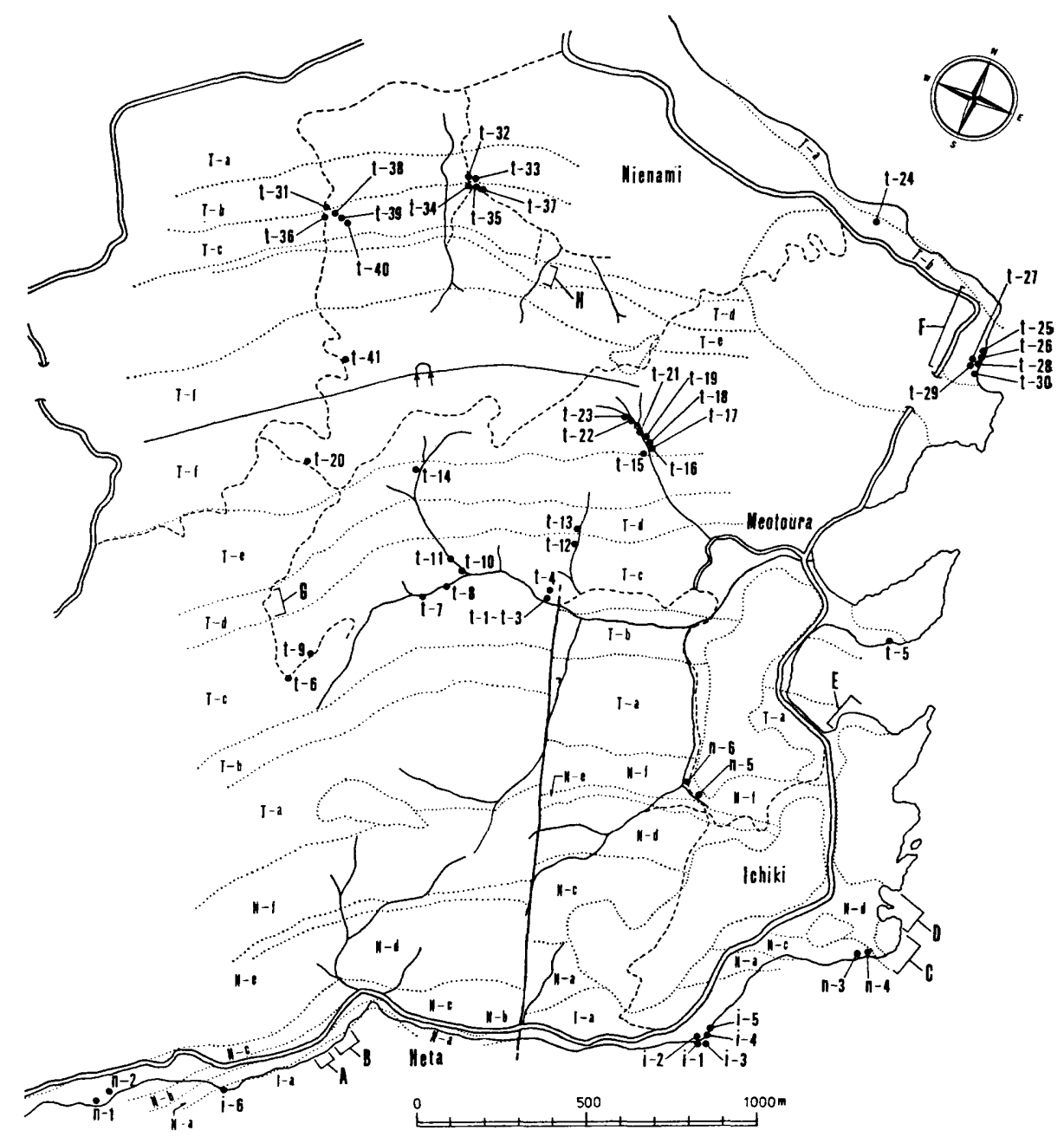

Fig. 2. Map showing planktonic foraminiferal fossil-localities and routes along which columnar sections shown in Figs. 3 to 8 were measured.

I-a; Ichiki Formation, N-a to N-f; Nango Formation, T-a to T-f; Takigahirayama Formation.

The sandstone beds of the alternating unit are fine- to very fine-grained, usually less than $10 \mathrm{~cm}$, rarely up to $30 \mathrm{~cm}$ thick, and show a constant bedthickness so far as is seen on the exposures as wide as 20 to $30 \mathrm{~m}$. They have planar and sharp bottom surfaces, being occasionally accompanied with flute and groove marks, and are bounded by a sharp top surface exhibiting smallscale, asymmetrical ripples (Pl. 38, Fig. 1). Thus, many of the sandstone beds show a distinct grain-size discontinuty at the base and top to the underlying and overlying mudstone beds, respectively, but those less than 4 to $5 \mathrm{~cm}$ thick are commonly gradational with the overlying mudstone. Most of the sandstone beds internally display either sets of parallel-laminae below and 


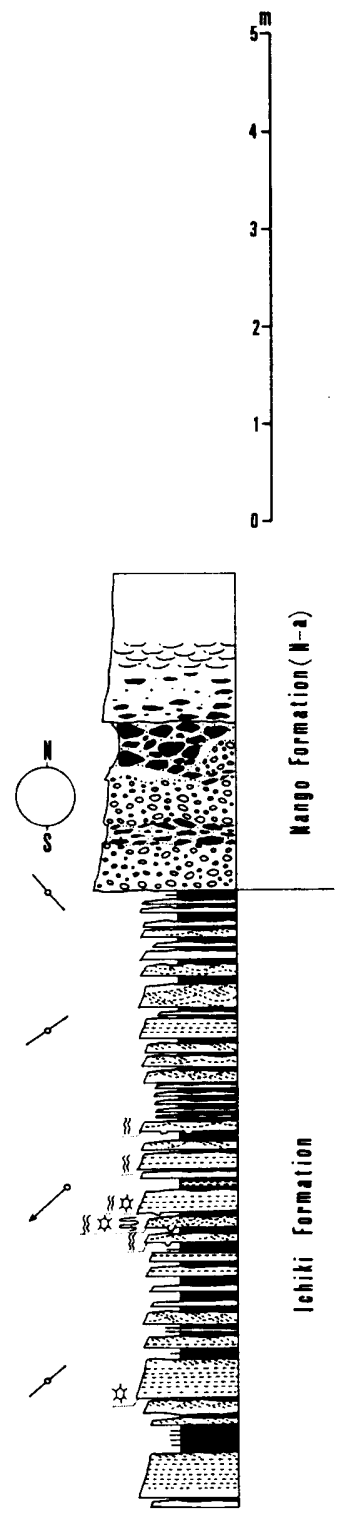

A

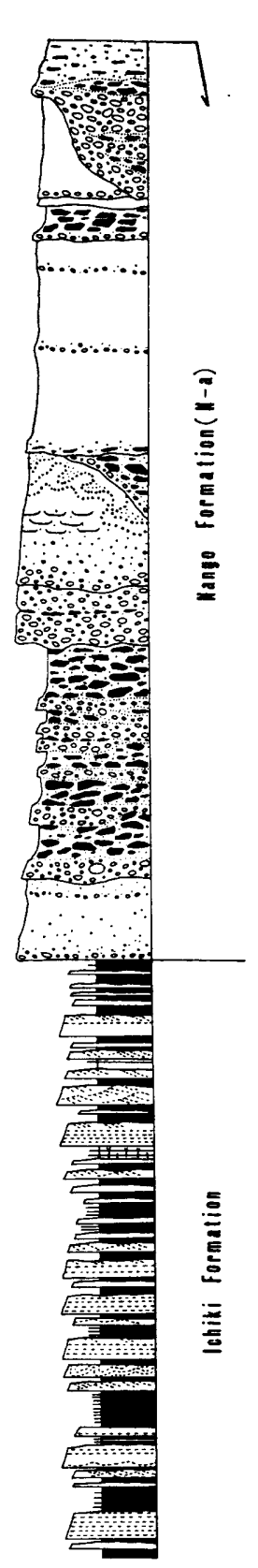

B
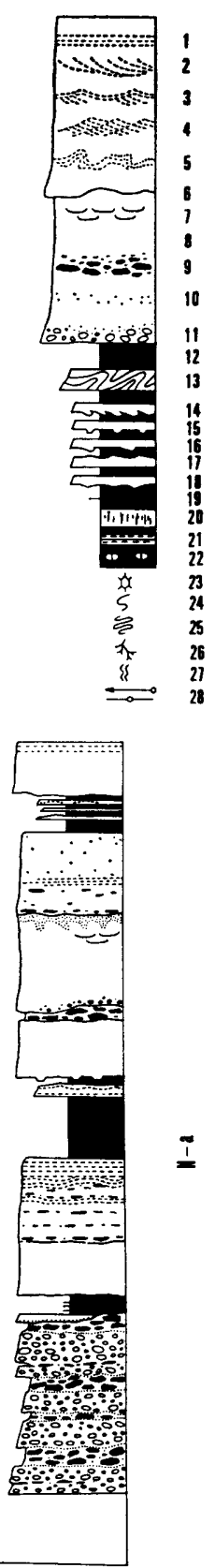

I

Fig. 3. Lithostratigraphic sequences of uppermost part of Ichiki Formation and lower part (N-a) of Lower Subformation of Nango Formation along Heta Coast ( $A$ and $B$ in Fig. 2).

1, parallel laminae; 2, cross laminae; 3, ripple-cross lamination; 4, climbing ripple-cross laminae; 5 , convolute structure; 6 , erosion surface; 7 , dish structure; 8 , sandstone; 9 , mud clasts (shall-pebble); 10 , pebbly sandstone; 11 , conglomerate; 12 , mudstone; 13 , slump bed; 14, flame structure; 15, load cast; 16 flute cast; 17 , ripple mark; 18 , load ripple mark; 19 , sandstone bed less than $5 \mathrm{~cm}$ in thickness; 20 , bioturbation; 21 , siltstone bands; 22 , calcareous concretion; 23 , Paleodictyon sp.; 24, Helminthopsis sp.; 25, Helminthoida sp.; 26, Chondorites sp.; 27, other trace fossils; 28, paleocurrent direction. 
asymmetric ripple-cross laminae above or cross-laminae throughout the thickness of a bed, and are lacking in a massive or graded interval at the base, although some thicker beds have this interval. These features suggest that many of the sandstone beds are base-missing turbidites. Furthermore the distinct grain-size discontinuity between the sandy portion and the overlying mudstone in many beds may have probably been caused by reworking of sediment of the upper parallel laminae due to bottom or contour currents. The mudstone beds are mostly structureless.

The trace fossils comprising crawling and feeding type are occasionally found on the top surfaces of mudstone. Helminthopsis sp., Helminthoida sp., Paleodictyon sp., and Nerites sp. are recognized (Fig. 3). The mudstone yields planktonic and benthic Foraminifera, of which the latter is much common.

\section{Nango Formation}

The Nango Formation is exposed in the southern part of the study area ( N-a to N-f in Fig. 1) and overlies the Ichiki Formation with a sharply defined scoured base. This Formation is about $400 \mathrm{~m}$ thick and is divided into Lower and Upper Subformations, each of which is characterized by a thinning- and fining-upward sequence which begins with conglomerate or sandstone, passes upward alternating beds of sandstone and mudstone, and ends with mudstone.

\section{a. Lower Subformation}

Type locality: Along the Heta Coast

Thickness: $140 \mathrm{~m}$

This subformation consists of conglomerate and sandstone $(25 \mathrm{~m})$ in the basal part ( $\mathrm{N}-\mathrm{a}$ in Fig. 9), alternating beds of sandstone and mudstone $(30 \mathrm{~m})$ in the middle $(\mathrm{N}-\mathrm{b})$, and incipiently bedded mudstone $(85 \mathrm{~m})$ in the upper $(\mathrm{N}-\mathrm{c})$. This overlies the Ichiki Formation with a marked scoured basal surface, on which northwest-southeasterly directed linear grooves cut into the underlying beds are recognized.

The basal member ( $\mathrm{N}-\mathrm{a})$ is composed of interbeds of conglomerate and pebbly coarse-grained to medium-grained sandstone, and shows an overall fining- and thinning-upward sequence (Fig. 3). Each bed has an irregularly scoured base and exhibits remarkable lateral changes of bed thickness. The conglomerate includes two types of lithologies: the one is poorly sorted conglomerate consisting of rounded, small pebbles and granules of sandstone, chert, siliceous shale, and a small amount of quartz-arenite (orthoquartzite) and acid igneous rocks. Small, angular fragments of black shale are also dispersed. The matrix is coarse to medium sand. The other is shale-pebble conglomerate composed of angular to subangular, flat-shaped black shale fragments ( $\mathrm{Pl}$. 38, Fig. 2). These shale clasts are variable in size generally ranging from $1 \mathrm{~cm}$ to 40 $\mathrm{cm}$. They are matrix-supported and exhibit random fabric throughout the bed or locally being oriented subparallel to the bedding surfaces. The matrix content is variable and consists of very coarse to medium-grained sand. The conglomerate beds of these two types are internally disorganized and often form composite beds which show abrupt lateral changes of bed thickness and lithologies. 
The sandstone beds of the basal member are $30 \mathrm{~cm}$ to $2 \mathrm{~m}$ thick, and often form amalgamated beds. Each bed has a scoured base, being accompanied by flute casts, and internally show a sequence beginning with pebbly, very coarsegrained sandstone often containing shale-clasts, and followed by massive or graded, coarse- to medium-grained sandstone in the main part and massive to weakly or distinctly parallel- and cross-laminated, medium-grained sandstone at the top. Thus the sandstone beds display the $\mathrm{T}_{\mathrm{a}-\mathrm{b}}$ or rarely $\mathrm{T}_{\mathrm{a}-\mathrm{c}}$ intervals of $\mathrm{a}$ turbidite. Dish structures are commonly developed in the main part and the laminated layers at the top often display convolute or flame structures.

The sandstone beds of the basal member are succeeded by alternating beds of medium- to fine-grained sandstone and mudstone (N-b), which range in thickness from 5 to $30 \mathrm{~cm}$ in the lower part and from 5 to $10 \mathrm{~cm}$ in the upper. The sandstone beds are sharp-based, and are accompanied by sole marks including flute and groove casts on the bottom surfaces. Many of them represent $T_{b-d}$ divisions of the Bouma sequences, although $T_{d}$ is very thin or incipient, and are followed by mudstone.

This alternating unit gradationally passes into a massive mudstone unit of the upper member ( $\mathrm{N}-\mathrm{c})$. In the main part of this unit no sandy layers are found, but in the upper part, thin layers of fine-grained sandstone and siltstone commonly occur. The sandstone beds display internal bedding characteristics including $\mathrm{T}_{\mathrm{b}-\mathrm{d}}$ or $\mathrm{T}_{\mathrm{c}-\mathrm{d}}$ divisions of turbidites.

\section{b. Upper Subformation}

Type locality: Along the coast east of Ichiki and a wood-land path north of Ichiki

Thickness : $270 \mathrm{~m}$

The Upper Subformation consists of conglomerate and sandstone (N-d: $135 \mathrm{~m}$ ), alternating beds of sandstone and mudstone (N-e: $50 \mathrm{~m}$ ), and mudstone (N-f: $85 \mathrm{~m}$ ) in ascending order (Fig. 9). This subformation is similar in lithologic sequence to the Lower Subformation, but is twice as thick as the latter. The lower member is well exposed along the coast east of Ichiki, but the middle and upper members are covered by the Upper Miocene Miyazaki Group there. Therefore, the exposures along a wood-land path north of Ichiki are designated as the type section of the middle and upper members.

The base of this subformation is exposed on the coast east of Ichiki, where a $4 \mathrm{~m}$ thick conglomerate bed has cut into thin-bedded sandstone and shale of the Lower Subformation, and flute marks can be seen on the bottom surface. This basal conglomerate is of granule to small pebble grade, and is lithologically similar to the pebble conglomerate of the Lower Subformation. It is disorganized in the main part, but rough stratification and grading can be recognized in the uppermost part (Fig. 4, C-section).

The lower member ( $\mathrm{N}-\mathrm{d}$ ) is composed of pebbly to very coarse-grained sandstone and intraformational shale-pebble conglomerate (Fig. 4, C-section). The sandstone beds in the lower part of the member are 1 to $5 \mathrm{~m}$ thick, often forming amalgamated beds, and individual beds are mainly massive or structureless, but are graded and parallel-laminated towards the top. Those of the middle 


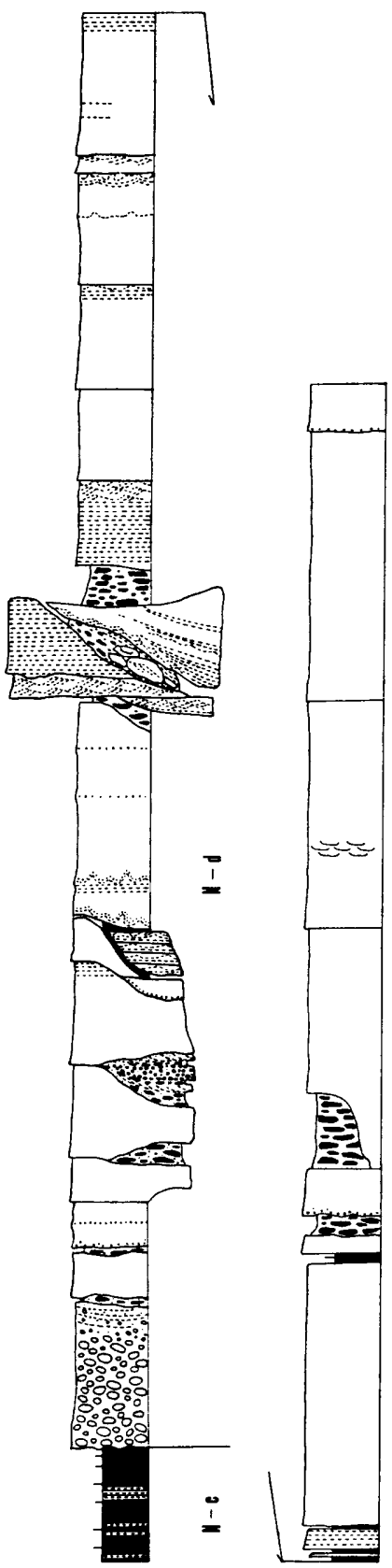

C

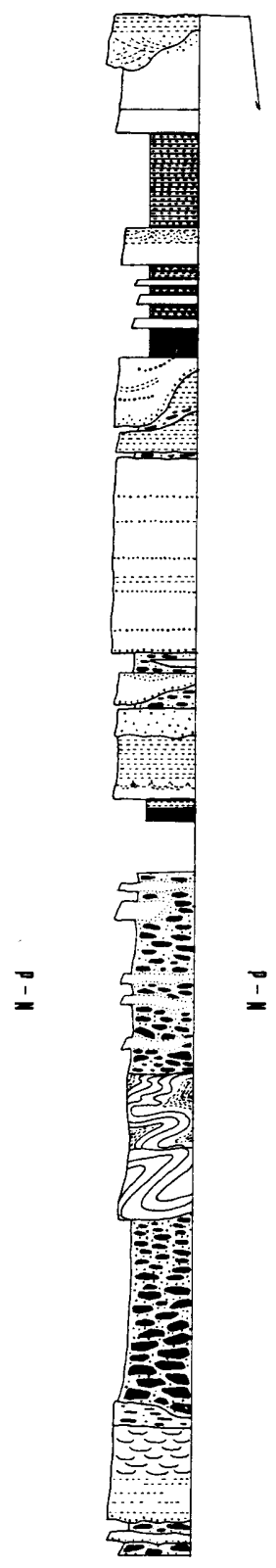

D

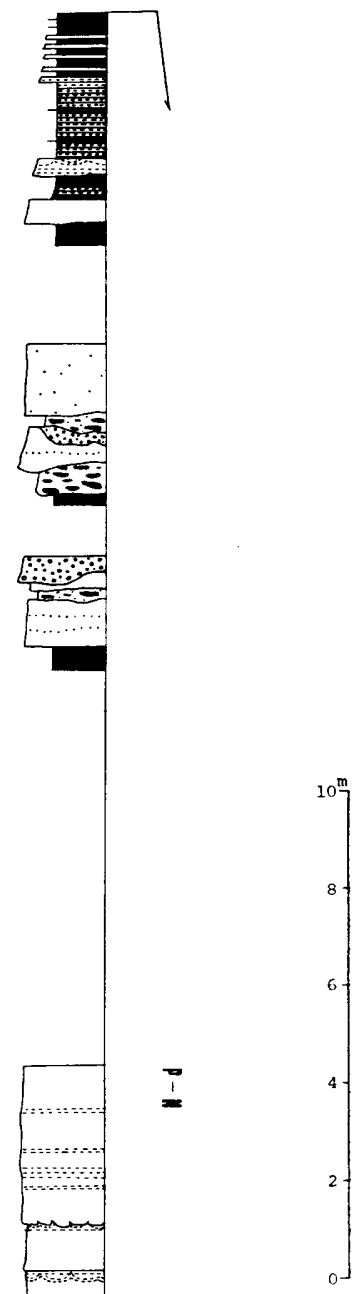

Fig. 4. Lithostratigraphic sequences of lower part of Upper Subformation (N-d) of Nango Formation along sections $C$ and $D$, shown in Fig. 2. See Fig. 3 for symbols. 
part are mostly more than $5 \mathrm{~m}$ in thickness, have greater lateral bed continuity than those of the lower, and are massive throughout the thickness. Dish structures are occasionally developed. The sandstone beds of the upper part are less than $3 \mathrm{~m}$ in thickness, and commonly form amalgamated beds (Fig. 4, D-section). Each bed has a scoured base, and often shows an internal sequence grading upward from a pebbly or very coarse-grained part to a medium- or finegrained, parallel and rarely ripple-cross laminated top, thus displaying the $\mathrm{T}_{\mathrm{a}-\mathrm{b}}$ or $\mathrm{T}_{\mathrm{a}-\mathrm{c}}$ divisions of the Bouma sequence. The laminated part at the top commonly exhibits convolute or flame structures.

The lower member includes shale-pebble conglomerate at many levels as shown in C- and D-sections of Fig. 4. The conglomerate beds are lenticular to wedge-shaped, show abrupt lateral changes of bed-thickness, have a scoured base, and cut into the underlying beds. As they are very similar in lithologic features to the shale-pebble conglomerate of the Lower Subformation, description on them are herein omitted. Further noteworthy is that this member includes chaotic deposits at two levels. The lower one consists of large sandstone blocks surrounded by a mixture of smaller sandstone blocks and black shale clasts (Fig. 4, C-section), and the upper one of broken and contorted beds and slump masses of thinly interbedded sandstone and shale floating in shale-pebble conglomerate. The slump masses show soft-sediment folds (Fig. 4, D-section).

The lower member rather rapidly passes into the middle member ( $\mathrm{N}-\mathrm{e}$ in Fig. 9) which is made up of alternating beds of fine-grained sandstone and mudstone. In the lower part sandstone predominantes over mudstone and is 10 to $30 \mathrm{~cm}$ thick bedded, but the upper part consists predominantly of shale with interbeds of 3- to $5-\mathrm{cm}$ thick sandstone. The sandstone beds have non-scoured but sharp bases, and a set of sandstone and mudstone displays $\mathrm{T}_{\mathrm{a}-\mathrm{e}}$ or $\mathrm{T}_{\mathrm{b}-\mathrm{e}}$ sequences of turbidites.

The middle member represents a thinning- and fining-upward sequence as mentioned above and is transitionally followed by the upper member ( $\mathrm{N}-\mathrm{f}$ ), which consists largely of massive mudstone with occasional thin silty bands or laminae. However, towards the top silty bands become thicker and coarser, and increase in number of beds. Thus this member changes into a packet of predominantly sandstone with thin interbeds of mudstone or siltstone in the uppermost $10 \mathrm{~m}$. In this part the sandstone beds are usually 10 to $30 \mathrm{~cm}$, rarely up to $1 \mathrm{~m}$ thick and show internal bedding characteristics of turbidite sequences $T_{a-e}$ although $T_{b-d}$ intervals are usually very thin.

The mudstone of the upper member yields benthic and planktonic Foraminifera, of which the latter was obtained from two levels.

\section{Takigahirayama Formation}

The Takigahirayama Formation crops out in the central and northern parts of the investigated area (Fig. 1). The thickness of the exposed sequence is $780 \mathrm{~m}$. This formation is divisible into two subformations on the basis of major cycles of lithologic sequences. 


\section{a. Lower Subformation}

Type locality: Along the coast south of Meotoura

Thickness: $460 \mathrm{~m}$

The Lower Subformation is distributed in the central and northernmost part of the investigated area (Fig. 1). This subformation conformably follows the Nango Formation, and is made up of predominantly thick- to very thickbedded sandstone $(200 \mathrm{~m}$ ) in the lower (T-a in Fig. 9), alternating beds of sandstone and mudstone $(105 \mathrm{~m})$ in the middle $(\mathrm{T}-\mathrm{b})$, and mudstone with some thin intercalations of siltstones $(155 \mathrm{~m})$ in the upper $(\mathrm{T}-\mathrm{c})$. Thus, this subformation displays a thinning- and fining-upward sequence. The base of this subformation is placed at the level of the first appearance of very thick sandstone more than $1 \mathrm{~m}$.

The sandstone beds of the lower menber (T-a) are mostly $50 \mathrm{~cm}$ to $2 \mathrm{~m}$ thick, well-sorted and medium- to fine-grained, and show planar and parallel bedforms with laterally uniform bed-thickness so far as is seen at the exposures (Pl. 38, Fig. 3). Their bottom surfaces are sharp, but no distinct scouring structures are found, although load casts are commonly present. Their tops are often rippled with a climb and rapidly upward into silty mudstone. Each bed internally displays either parallel laminae almost throughout the thickness or a set of parallel laminae below and asymmetrical cross laminae above (T-a: $E$ and $F_{1}$ in Fig. 5; Fig. 6). The cross laminae are frequently represented by climbing ripples, but sometimes by low undulating laminae. The division of parallel laminae exhibits very clear parting lineation and occasionally contains concentration of plant fragments at some laminae. Some thick beds have a massive interval at the basal part, in which black-shale clasts less than a few $\mathrm{cm}$ are commonly contained. The bedding characteristics of the sandstone of the lower part indicate the $\mathrm{T}_{\mathrm{b}-\mathrm{c}}$ rarely $\mathrm{T}_{\mathrm{a}-\mathrm{c}}$ sequence of turbidites.

The lower member is transitionally succeeded by alternating beds of medium- to thin-bedded sandstone and mudstone of the middle member ( $\mathrm{T}-\mathrm{b}$ in Figs. 5, 6 and 7). It shows an overall thinning- and fining-upward sequence, although several repititions of minor cycles are recognized in the lower part of the member on the northern limb of the Nango Syncline (Figs. 6 and 7). The sandstone beds are well-sorted and generally fine- to very fine-grained. Those thicker $30 \mathrm{~cm}$ are generally characterized by a set of parallel laminae below and asymmetrical cross laminae above, but thinner ones are predominated by either parallel or cross laminae. Parallel laminae above the cross laminae intervals are mostly very thin or incipient. The bottom surfaces are sharp and are commonly associated with flute and groove marks. At the top, the sandstone beds show an abrupt changes in grain-size into the overlying mudstone and when marked by ripples they show a sharp boundary (Pl. 38, Fig. 4). Thus, the sandstone beds represents the $\mathrm{T}_{\mathrm{b}-\mathrm{e}}$ or $\mathrm{T}_{\mathrm{c}-\mathrm{e}}$ sequence of turbidites, although $T_{d}$ division is not uncommonly lacking. The crawling- and feeding-type trace fossils including Helminthoida sp., Helminthopsis sp., Paleodictyon sp., and Chondrites sp. are commonly recognized at the top surfaces of mudstone beds.

The middle member transitionally grades up into the upper member (T-c) which consists mostly of darkgray massive mudstone with occasional thin very 

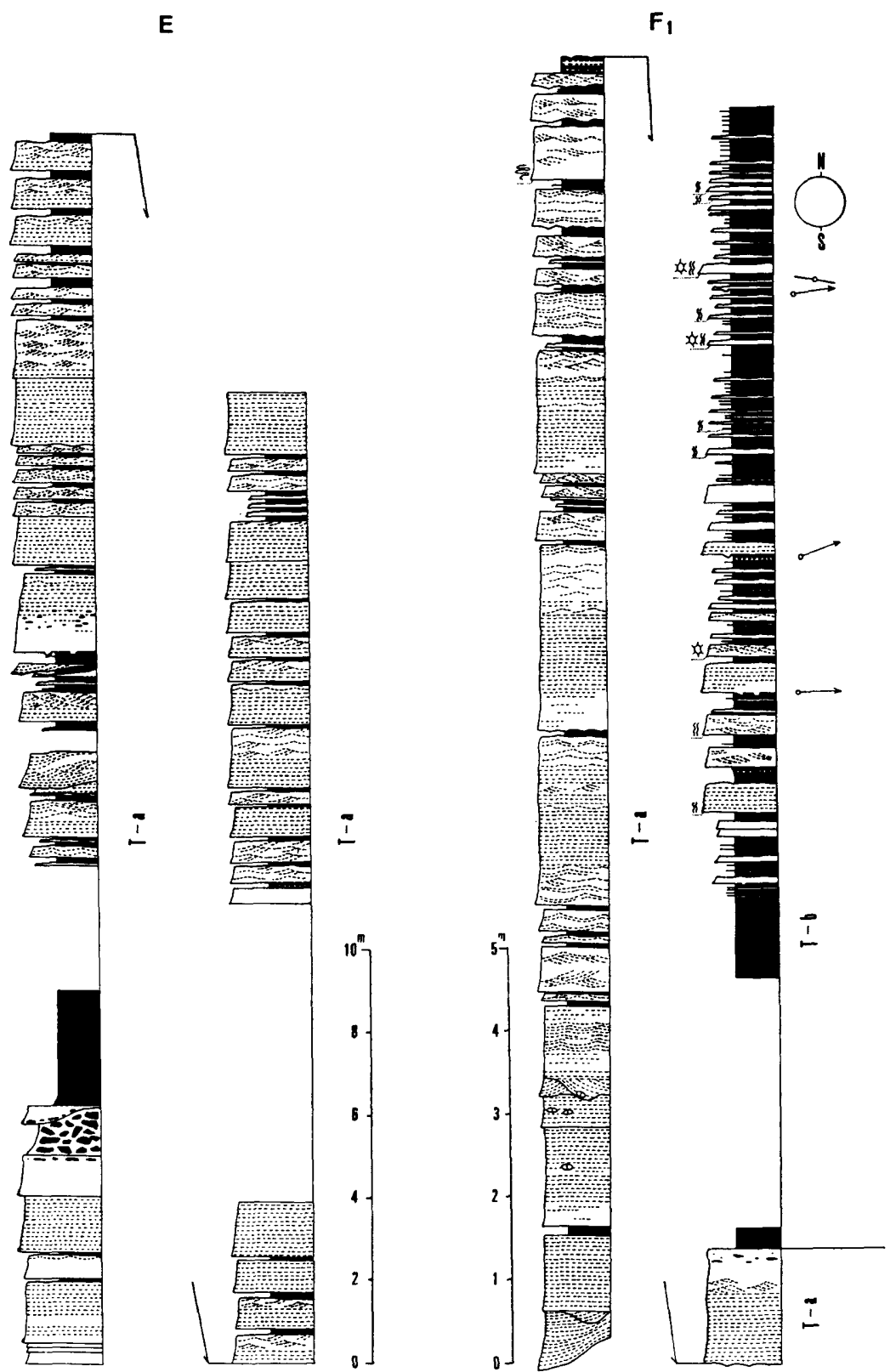

Fig. 5. Lithostratigraphic sequence of Lower Subformation of Takigahirayama Formation along sections $\mathbf{E}$ and $\mathbf{F}$ (northern half) shown in Fig. 2. See Fig. 3 for symbols.

$\mathrm{E} ; \mathrm{T}$-a to south of Meotoura, $\mathrm{F}_{1} ; \mathrm{T}-\mathrm{a}$ to $\mathrm{T}-\mathrm{b}$ on coast southeast of Nienami. 


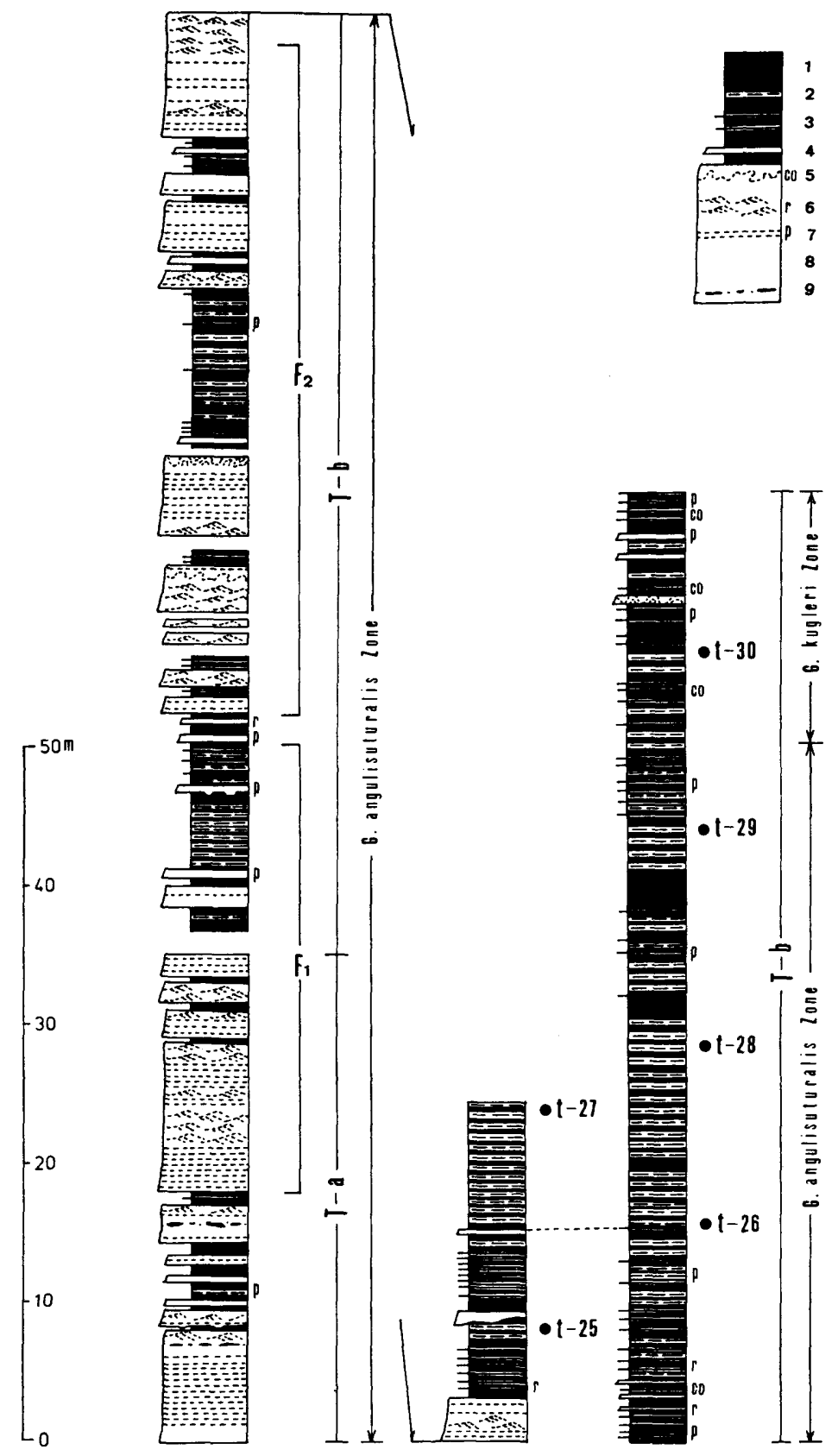

Fig. 6. Lithostratigraphic sequences of Lower Subformation (T-a and T-b) of Takigahirayama Formation along the section $\mathbf{F}$ on the coast southeast of Nienami. 1 , mudstone; 2, sandstone less than $5 \mathrm{~cm}$ in thickness; 3 , sandstone less than $10 \mathrm{~cm} ; 4$, sandstone less than $30 \mathrm{~cm} ; 5$, convolute laminae; 6 , ripple-cross laminae; 7 , parallel laminae; 8 , sandstone; 9 , mudstone clasts (shale-pebble). Detailed sequence is shown as $F_{1}$ in Fig. 5 and $F_{2}$ in Fig. 7. 
fine-grained sandstone and siltstone layers. Several pale-green tuff beds less than $5 \mathrm{~cm}$ thick are intercalated in the middle part, and calcareous concretions, up to $10 \mathrm{~cm}$ across, are sporadically found.

The upper part of the middle member on the northern limb and the upper member yield planktonic and benthic Foraminifera, and Radiolaria.

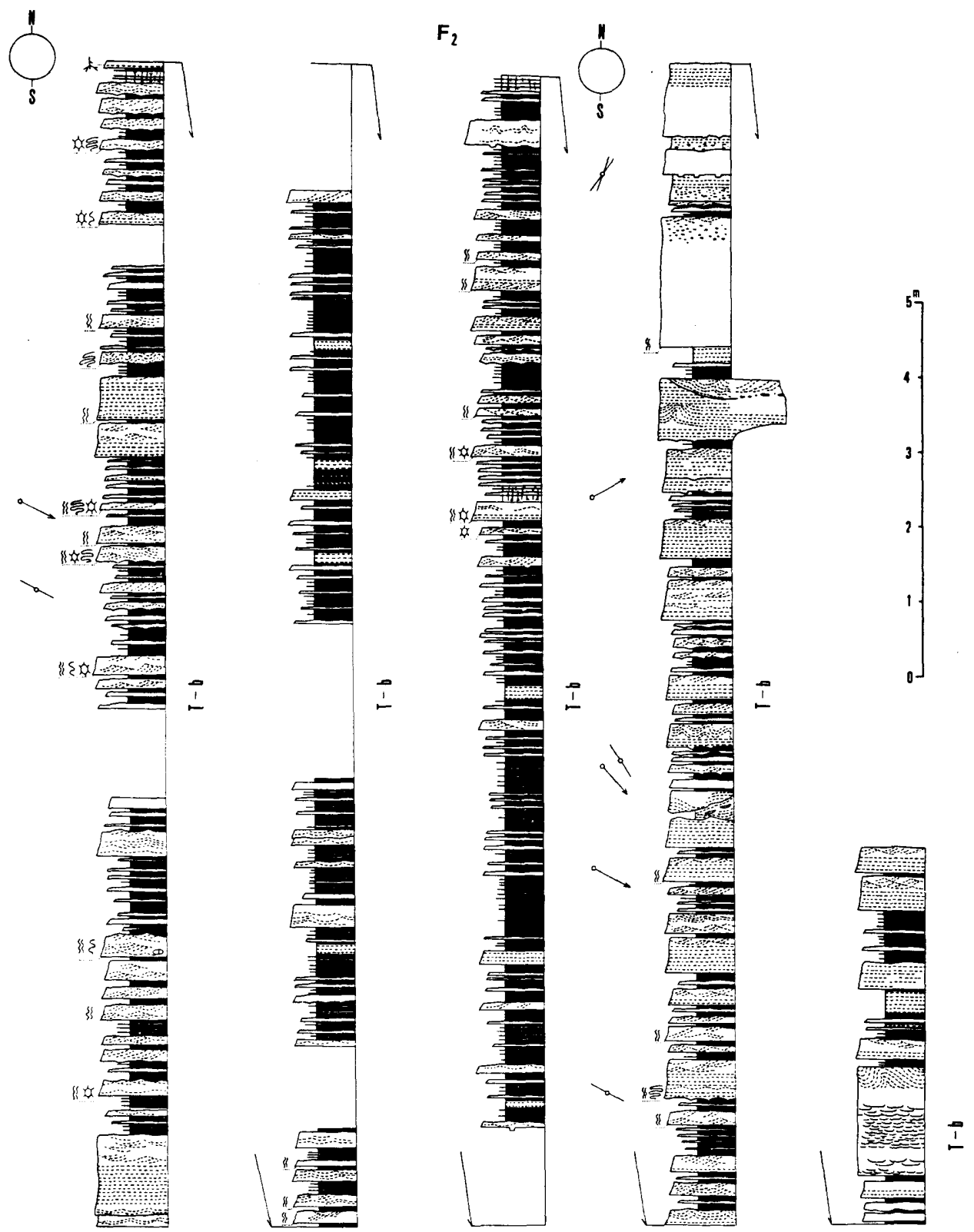

Fig. 7. Lithostratigraphic sequence of Lower Subformation of Takigahirayama Formation (T-b) along section F (southern half) shown in Fig. 2. See Fig. 3 for symbols. 


\section{b. Upper Subformation}

Type locality: A northwesterly running small valley $200 \mathrm{~m}$ west of Meotoura

Thickness : $320 \mathrm{~m}+$

G

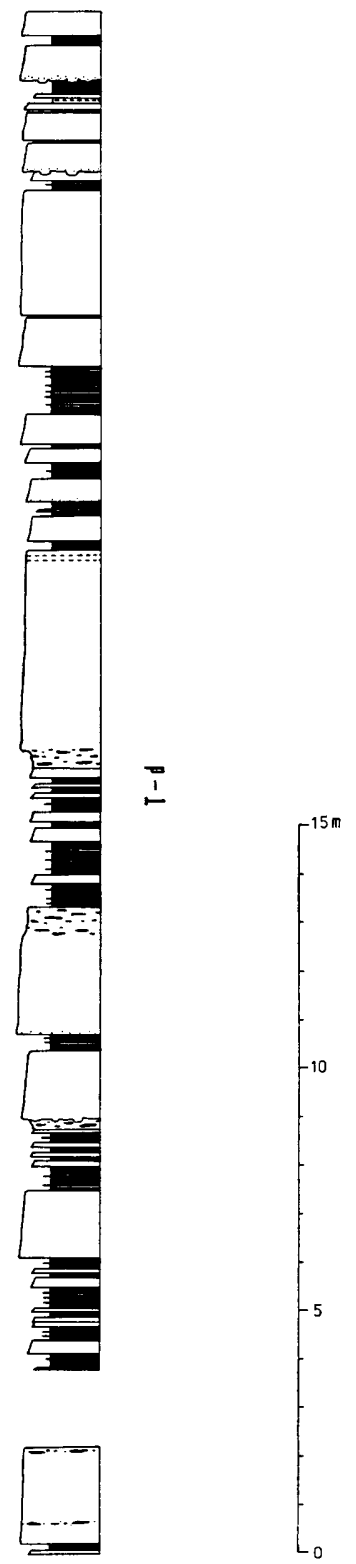

H
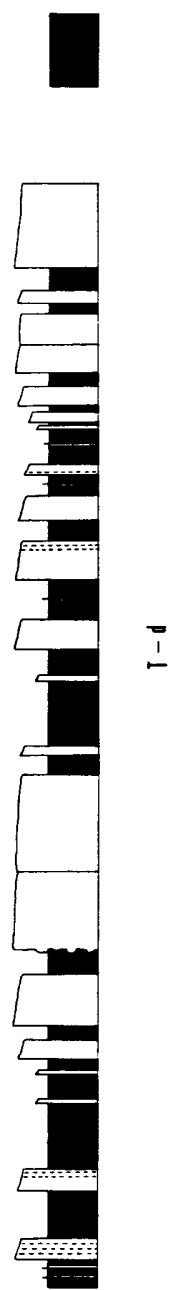

Fig. 8. Lithostratigraphic sequence of Upper Subformation of Takigahirayama Formation along sections $\mathrm{G}$ and $\mathrm{H}$ shown in Fig. 2. See Fig. 3 for symbols. 
The Upper Subformation conformably follows the Lower Subformation and its base is artificially placed at the bottom of a packet of alternating beds of sandstone and mudstone first appeared above the mudstone of the T-c member. It is composed of alternating beds of sandstone and mudstone $(80 \mathrm{~m})$ in the lower part (T-d in Fig. 9), thick-bedded sandstone $(70 \mathrm{~m}$ ) in the middle (T-e) and mostly mudstone $(170 \mathrm{~m})$ in the upper (T-f). Thus this subformation shows a facies cycle composed of a thickening- and coarsening-upward sequence and the following thinning- and fining-upward one. In this cycle the lithofacies change from $\mathrm{T}$-e to $\mathrm{T}-\mathrm{f}$ is much more rapid than that from $\mathrm{T}-\mathrm{d}$ to $\mathrm{T}$-e.

The lower member (T-d) is a sequence of predominantly mudstone with subordinate very thin interbeds of very fine-grained sandstone and siltstone in the lower part and with 5 to $20 \mathrm{~cm}$ thick, fine-grained sandstone interbeds in the upper. These sandstone beds exhibit the $\mathrm{T}_{\mathrm{a}-\mathrm{e}}$ sequence of turbidites. However, in the western part of the investigated area and the eastern part of the overturned limb this member contains some sandstone beds as thick as 1 to 4 $\mathrm{m}$ (Fig. 8). The middle member (T-e) consists largely of thick to very thickbedded, medium-grained sandstone with 10 to $30 \mathrm{~cm}$ thick mudstone interbeds. Each sandstone bed is largely massive with parallel laminae in the upper part. The base is sharp, but no erosional structures were found. Towards the top of this member sandstone becomes thinner-bedded and finer-grained.

The mudstone of the upper member ( $T-f)$ is massive and is occasionally accompanied with thin, very fine-grained sandstone and siltstone layers. Some tuff beds are found in the lower part.

As this subformation, especially the T-f member, is exposed in the mountain ridge area, the rocks are strongly weathered down to a few to several meters deep from the land surface. Therefore, microfossils have been found only from several localities from where fresh rock samples were obtained.

\section{Depositional Facies}

The Nichinan Group is characterized by cyclic vertical variations depicted by changes in sand/mud ratio and sandstone bed-thickness, although lithostratigraphic divisions have not been rendered to accord with these changes (Figs. 9 and 10). Each cycle consists of the following four facies-units in ascending order: (1) massive mudstone; (2) alternating beds of sandstone and mudstone which show a coarsening- and thickening-upward sequence; (3) very thickbedded, very coarse- to medium-grained sandstone accompanied with shale-pebble

\section{Explanation of Plate 38}

Fig. 1. Alternating beds of sandstone and mudstone of the uppermost part of Ichiki Formation. Note sharp bases and rippled surfaces.

2. Shale-pebble conglomerate (debris flow deposit) in lower member of Lower Subformation of Nango Formation.

3. Parallel- and ripple-laminated sandstone in lower member (T-a) of Lower Subformation of Takigahirayama Formation.

4. Alternating beds of sandstone and mudstone of middle member of Lower Subformation of Takigahirayama Formation. 

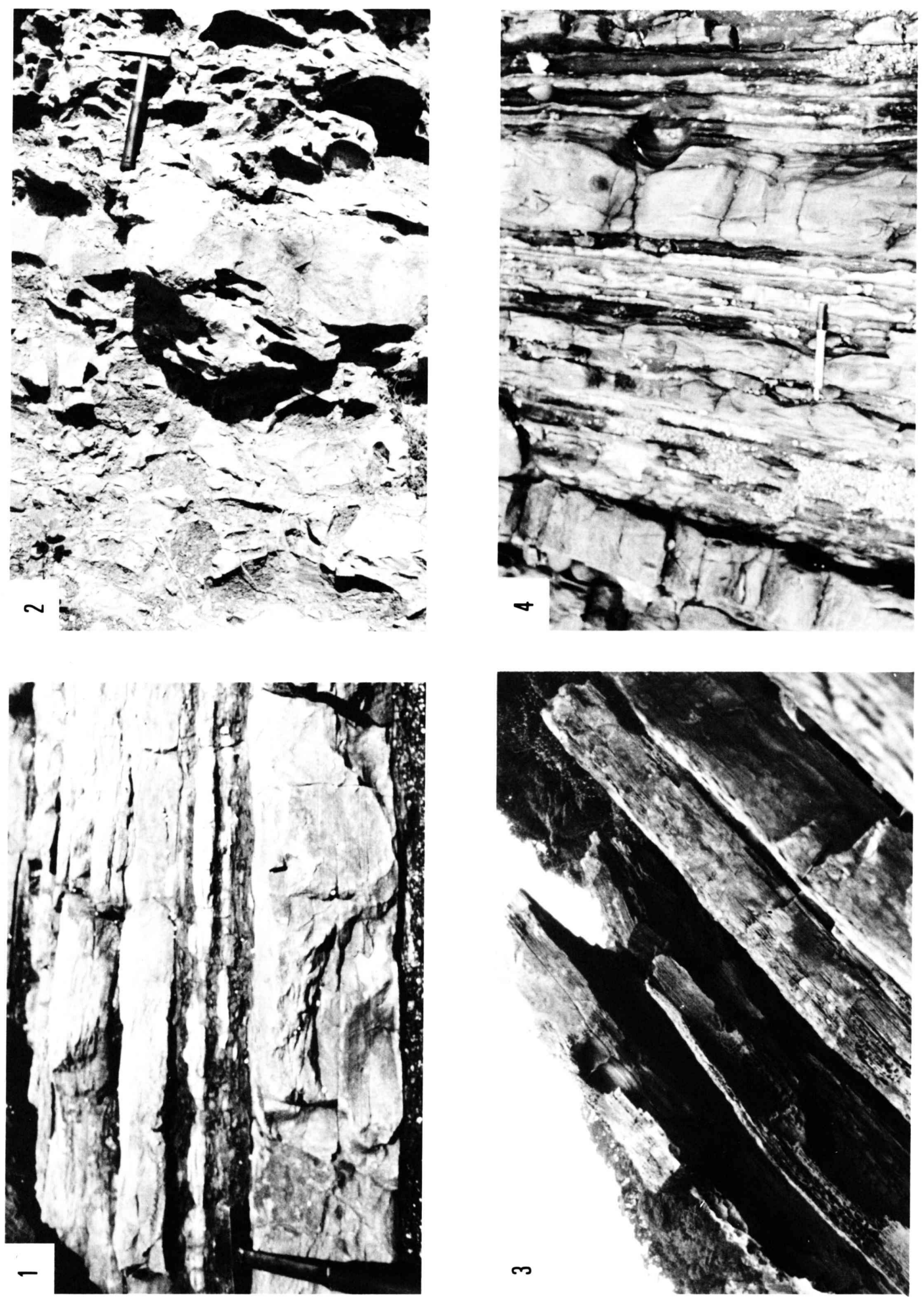

H. Nishi: Stratigraphy of Oligocene-Miocene Nichinan Group 
conglomerate; (4) alternating beds of sandstone and mudstone which exhibit a fining- and thinning-upward sequence. The last unit is overlain by a massive mudstone unit. Thus the Nichinan Group displays four cycles of prograding and retrograding sequences with regard to the intercalation of sandstone beds.

Among the facies-units mentioned above, the third one is represented by $\mathrm{N}-\mathrm{a}$ and $\mathrm{N}-\mathrm{d}$ members of the Nango Formation and $\mathrm{T}-\mathrm{a}$ and $\mathrm{T}-\mathrm{e}$ members of the Takigahirayama. The sandstone beds of $\mathrm{N}-\mathrm{a}$ and $\mathrm{N}-\mathrm{d}$ members have erosional bases cut into the underlying alternating beds, and those as thick as over $50 \mathrm{~cm}$ often show amalgamation of strate. These members include many wedge-beds of disorganized intraformational shale-pebble conglomerate. The associated very coarse-grained sandstone and well-rounded granule to small pebble conglomerate beds also show disorganized fabric and commonly exhibit dish structures in the main part and convolute structure at the top part of the beds. From these lithologic and bedding characteristics, the $\mathrm{N}-\mathrm{a}$ and $\mathrm{N}-\mathrm{d}$ members can be referred to as channel-fill debris flow deposits. On the other hand, T-a and T-e members are transitional from the underlying alternating bed unit. The sandstone beds of T-a member show planar and parallel bed-forms with nonchanneled bases, and represent base-missing, largely to entirely laminated, $\mathrm{T}_{\mathrm{b}-\mathrm{c}}$ predominant sequence of turbidites with incipient $\mathbf{T}_{\mathbf{d}}$ interval. These beds are considered to have resulted from dense and rapid turbidite currents and to have formed as suprafan sand-lobes. The sandstone beds of T-e member are finegrained, being sufficiently continuous laterally, and are characterized by prominent development of the $T_{a}$ interval with much less developed laminated intervals. These features suggest the deposition by highly concentrated turbidity flows with little traction effects. These beds may also be referred to as suprafan sand-lobe deposits.

The sandstone beds of the second and fourth alternating facies generally show planar bedding, and their bases are always sharp. Sole marks are most abundant and variable in these facies. The sandstone and mudstone couplets show various aspects in internal bedding characteristics; in some units, mainly in N-e, N-f and T-d members, they are gradational and show a complete Bouma sequence of turbidites, but in others, the sandstone part lack one or more of the upper intervals or basal ones. Especially base-missing turbidites are very common. The $T_{a}$ and $T_{d}$ intervals are often missing in the uppermost member of the Ichiki Formation, N-b member of the Nango and T-b member of the Takigahirayama. The $T_{d}$ interval is rarely visible or often difficult to distinguish from the $T_{c}$ interval in $T-b$ member of the Takigahirayama. Even in these units, however, the sandstone parts exhibit the set of parallel laminae at the base and cross laminae above, which suggests that the sandstone beds have resulted mainly from bottom traction of turbidites.

On the basis of sedimentary features of each facies-unit and the stratigraphic sequence and with reference to the knowledge on recent and ancient sedimentary bodies (e.g. MutTI and RICCI-LUCCHI, 1972), the depositional environments of the Nichinan Group are inferred as follows: the Ichiki Formation shows an abrupt increase of coarse sediment influx above a thick packet of massive mudstone, and is covered by debris flow deposits of the 
basal member of the Nango Formation. This lithologic change suggests that the Ichiki Formation is the deposits of a transitional sequence from an outer fan to a middle fan caused by the progradation of sediment distributary channels of a submarine fan. The Nango Formation includes two units of debris flow deposits, each of which is followed with rapid facies changes by the thinning-upward alternating sandstone and mudstone facies. The former can be attributed to channel-fill deposits, but the latter cannot be ascertained whether it is interchannel deposits resulted from lateral shifting of channels or outer fan deposits caused by the retrogradation of channels, because of structurally limited distribution of the Nichinan Group in the Nango block. The Takigahirayama Formation contains two thick-bedded sandstone units which are transitional with the underlying and overlying alternating sandstone and mudstone units. The thick sandstone units can probably be referred to as deposits of suprafan sand-lobes prograded into a middle fan and the alternating units as sand-lobe-fringe deposits formed by dilute turbidity currents.

It is concluded that the overall sequence of the Nichinan Group is comparable with the deposits in the outer to middle fan environments of a submarine fan. It shows repeated progradation and retrogradation of channel-fill and sandlobe deposits, and the upward thickening of muddy beds and the general upward fining of sandstone beds signify the major retrogradation of the fan deposition.

\section{Biostratigraphy of the Nichinan Group}

\section{A. Zonation of the Nichinan Group in the Nango area}

The Nichinan Group abundantly yields planktonic and benthic Foraminifera, and Radiolaria, although it includes some barren intervals represented by thick sandstone beds. Of samples collected from more than 300 localities, mudstone samples from 53 localities (Fig. 2) yielded datable planktonic Foraminifera (Tables 1 and 2). 40 species belonging to 8 genera were identified, and their stratigraphic distribution is shown in Figs. 9 and 10. The sequence examined can be biostratigraphically divided into the following three zones in ascending order: Globorotalia (Turborotalia) opima opima Zone, Globigerina angulisuturalis Zone, Globorotalia (Turborotalia) kugleri Zone. Representative species of these zones are shown in Plates 39 and 40.

\section{Globorotalia (Turborotalia) opima opima Zone}

The Ichiki Formation and the lower part of the Nango Formation can be referred to this zone (Fig. 9). The representative species of this zone are Globorotalia (Turborotalia) opima opima BoLlI, Globigerina pseudovenezuelana Blow and BANNer, G. corpulenta Subbotina, G. eocanena GüMBel, and $G$. gortanii BoRsETTI. Globigerina angulisuturalis BoLLI also occurs in this zone, and ranges up to the lower part of the Globorotalia kugleri Zone. The top of this zone is marked by the extinction of $G$. (T.) opima opima.

\section{Globigerina angulisuturalis Zone}

The upper part of the Nango Formation belongs to this zone, and the lower 


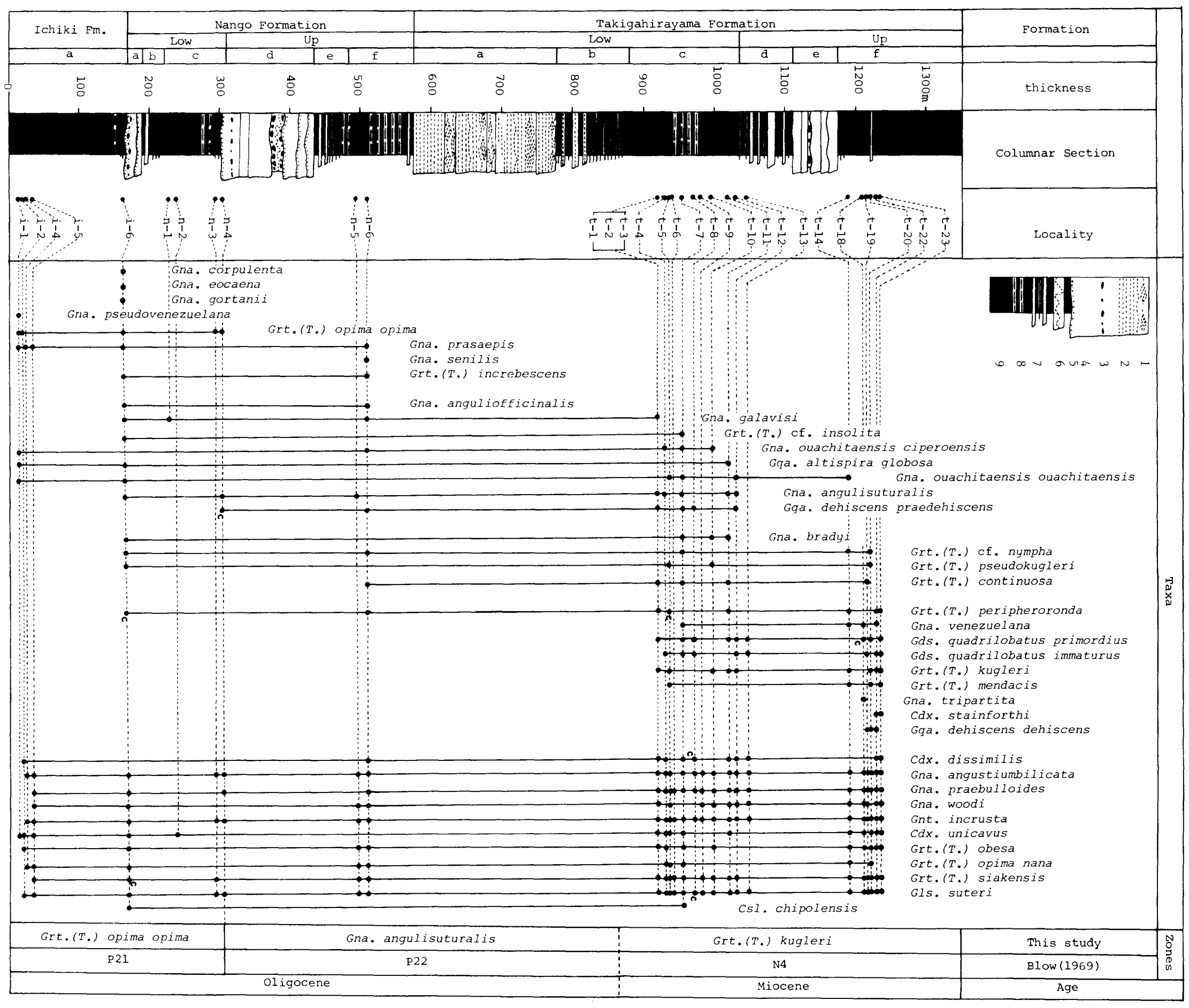

Fig. 9. Generalized lithostratigraphic sequence of Nichinan Group on southern limb of Nango Syncline and biostratigraphic distributions of planktonic Foraminifera.

1, ripple laminae; 2 , parallel laminae; 3 , mud clast (shale-pebble) ; 4, sandstone; 5 , conglomerate; 6 , slump beds; 7, alternating beds of sandstone and mudstone; 8 , siltstone bands; 9 , mudstone; c, confer; Gna., Globigerina; Gds., Globigerinoides; Cdx., Catapsydrax; Gnt., Globigerinita; Gqa., Globoquadrina; Grt. (T.), Globorotalia (Turborotalia) ; Gls., Globorotaloides; Csl., Cassigerinella. 
part of the Takigahirayama Formation may also be assigned to this zone (Fig. 9 ). The characteristic species of this zone are Globigerina angulisuturalis BOLLI, G. anguliofficinalis BLOW, G. galavisi BERMÚDEZ, and G. ouachitaensis ciperoensis BoLLI. The base of this zone is placed at the level of extinction of of G. (T.) opima opima as mentioned above. The upper limit is defined by the

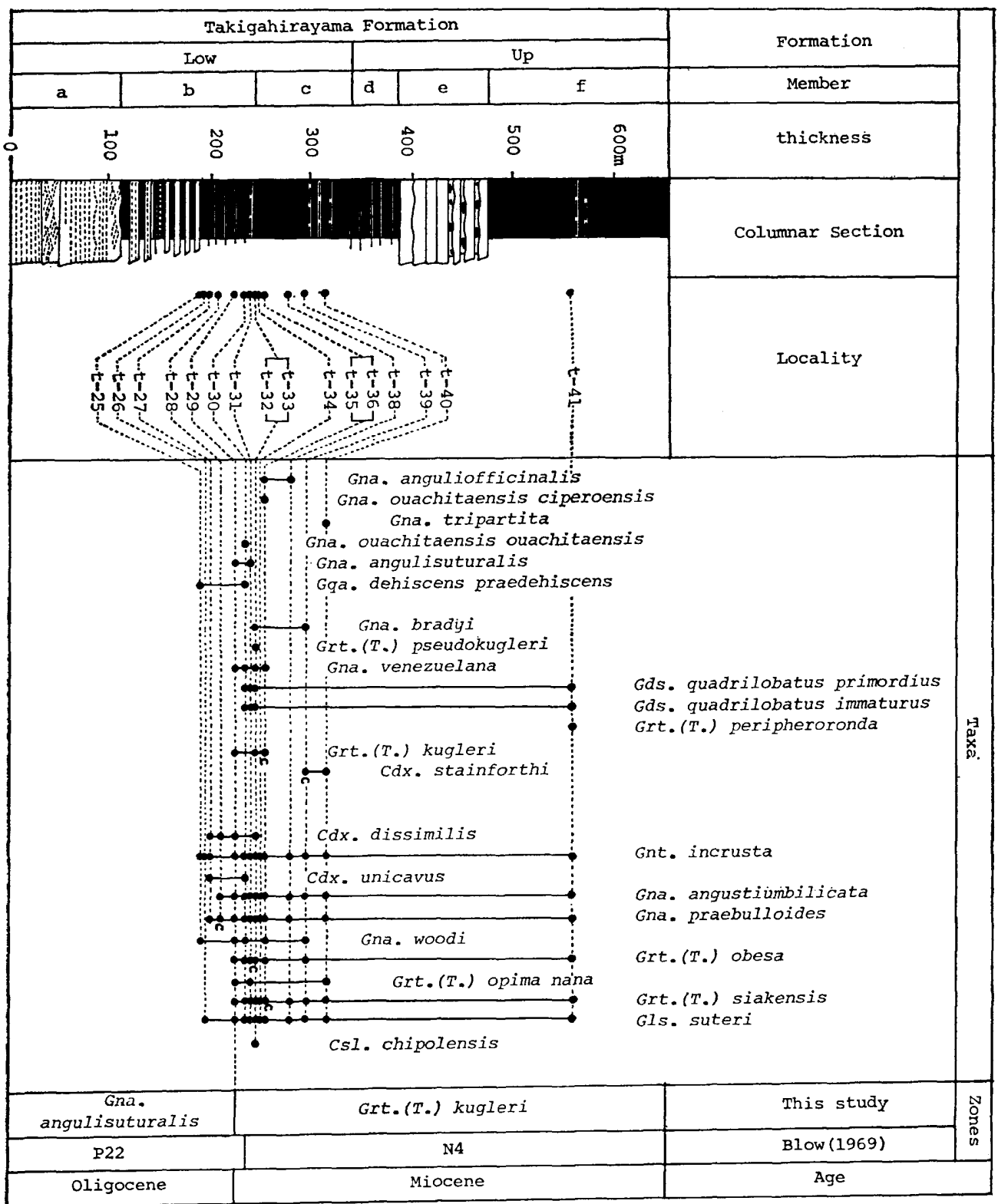

Fig. 10. Generalized lithostratigraphic sequence of Takigahirayama Formation in northern limb of Nango Syncline and biostratigraphic distribution of planktonic Foraminifera. Lithologic symbols are same as those of Fig. 9. 
first appearance of Globorotalia (Turborotalia) kugleri BoLLI and Globigerinoides quadrilobatus primordius BLOW and BANNER.

\section{Globorotalia (Turborotalia) kugleri Zone}

The middle and upper parts of the Takigahirayama Formation belong to this zone (Fig. 9). The diagnostic species of this zone include Globorotalia (Turborotalia) kugleri BoLlI, G. (T.) mendacis BLow, Globigerinoides quadrilobatus primordius BLOW and BANNER, G. quadrilobatus immaturus LEROY, Catapsydrax stainforthi (BOLLI, LOEBLICH and TAPPAN), Globorotalia (Turboratalia) peripheroronda BLOW and BANNER, and Globoquadrina dehiscens dehiscens (CHAPMAN, PARR and CoLlINS). Globorotalia (Turborotalia) pseudokugleri BLOW, Globigerina bradyi WIESNER, and Globoquadrina dehiscens praedehiscens BLOW and BANNER also commonly occur. The base of this zone can be demarcated by the first appearance of $G$. (T.) kugleri, G. quadrilobatus primordius, G. quadrilobatus immaturus.

In the section of the Nichinan Group on the southern limb of the Nango Syncline (Fig. 9), the base of this zone or the boundary between the G. kugleri and the underlying $G$. angulisuturalis Zone, can not be defined because of scantiness of planktonic Foraminifera. However, it was confirmed in the upper part of alternating beds of T-b member on the overturned limb of the syncline (Figs. 6 and 10 ), as noted above.

\section{B. Correlation and Geologic Age}

The Nichinan Group is not complete in fossil occurrence as there are barren spaces at four intervals represented by thick sandstone beds. However, two significant datum levels, the horizon of the extinction of $G$. (T.) opima opima and that of the initial appearance of $G$. (T.) kugleri and the species of Globigerinoides, were confirmed in the sections of this area. The former is equivalent to the boundary between Zone N. $2(=$ P. 21) and Zone N. $3(=$ P. 22) of BLow (1969), and the latter is correlative with the boundary between Zone N. $3(=\mathrm{P}$. 22) and Zone N. 4. It is known that Zone P. 21 or the Globigerina angulisuturalis and Globorotalia (Turborotalia) opima opima Concurrent-Range Zone of BLow (1969), the base of which is marked by the first appearance of G. angulisuturalis and the top by the extinction of $G$. (T.) opima opima, is characterized by $G$. (T.) opima opima, G. angulisuturalis, G. gortanii, G. ouachitaensis ouachitaensis, G. galavisi, Globigerina sellii BoRSETTI, and others. All of these species except $G$. sellii were discovered in this area. Therefore, the G. (T.) opima opima Zone in the Nichinan Group is correlated with Zone P. 21 of BLow (1969).

The G. angulisuturalis Zone of this area comprises such diagnostic species as $G$. angulisuturalis, G. ouachitaensis ciperoensis, and $G$. dehiscens praedehiscens which characterize Zone P. $22(=\mathrm{N} .3) . G .(T$.$) kugleri and the species$ of Globigerinoides which are diagnostic to Zone N. 4 have not been found in this zone. Therefore, this zone is correlated with Zone P. $22(=\mathrm{N} .3)$ or the Globigerina angulisuturalis Partial-Range Zone of BLoW (1969). 
Table 1. List of planktonic foraminiferal species from southern limb of Nango Syncline.

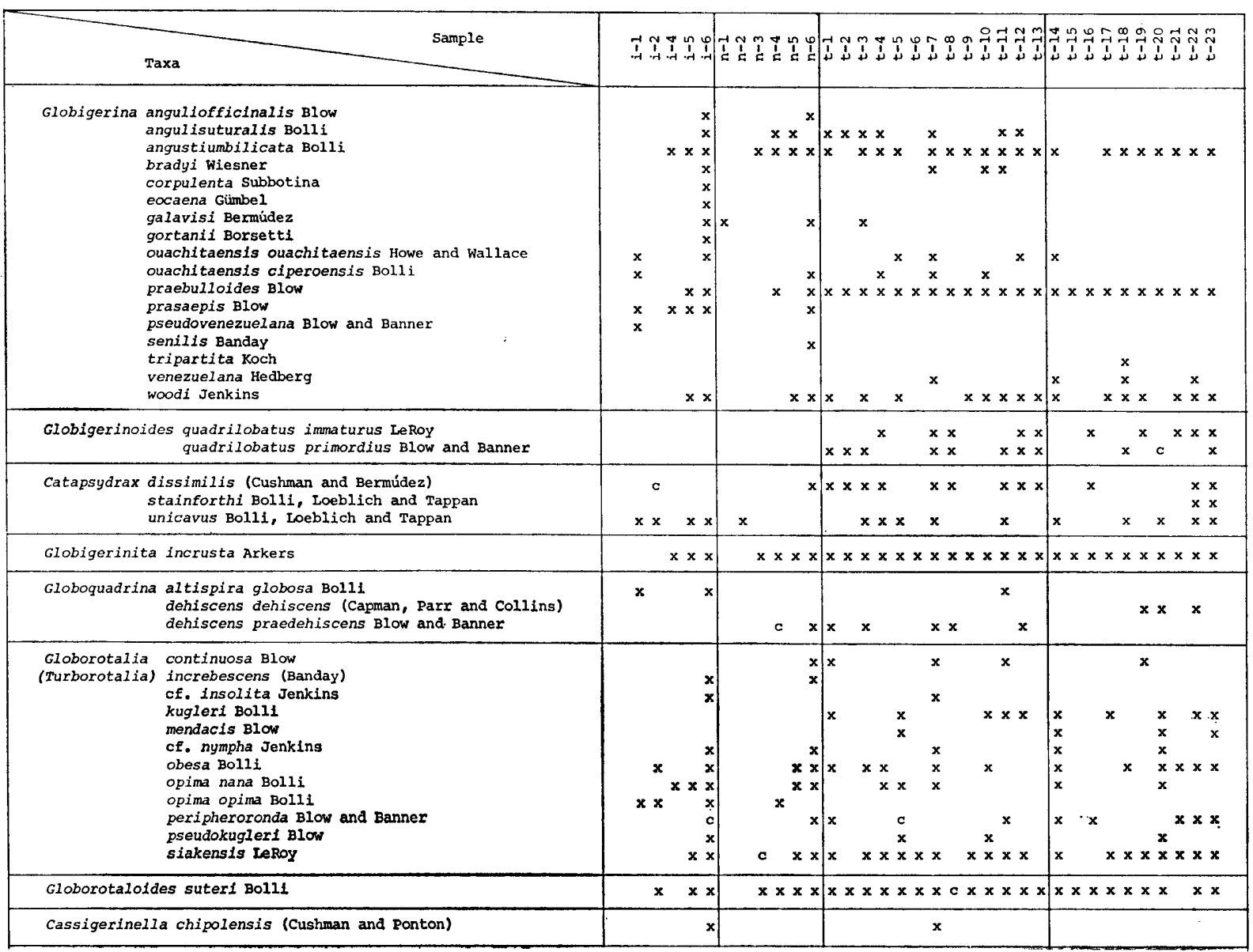


Table 2. List of planktonic foraminiferal species from northern limb of Nango Syncline.

\begin{tabular}{|c|c|}
\hline Sample & 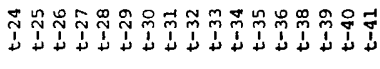 \\
\hline $\begin{array}{l}\text { Globigerina anguliofficinalis Blow } \\
\text { angulisuturalis Bolli } \\
\text { angustiumbilicata Bolli } \\
\text { bradyi Wiesner } \\
\text { ouachitaensis ouachitaensis Howe and wallace } \\
\text { ouachitaensis ciperoensis Bolli } \\
\text { praebulloides Blow } \\
\text { tripartita Koch } \\
\text { venezuelana Hedberg } \\
\text { woodi Jenkins }\end{array}$ & 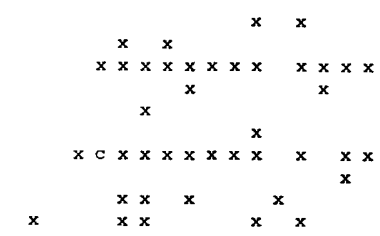 \\
\hline $\begin{aligned} \text { Globigerinoides } & \text { quadrilobatus immaturus LeRoy } \\
& \text { quadrilobatus primordius Blow and Banner }\end{aligned}$ & $\begin{array}{lll}\mathbf{x} & \mathbf{x} & \mathbf{x} \\
\mathbf{x} & \mathbf{x} & \mathbf{x}\end{array}$ \\
\hline $\begin{aligned} \text { Catapsydrax dissimilis (Cushman and Bermúdez) } & \begin{aligned} \text { stainforthi Bolli, Loeblich and Tappan } \\
\text { unicavus Bolli, Loeblich and Tappan }\end{aligned}\end{aligned}$ & $\begin{array}{l}\mathrm{x} \times \mathrm{x} \\
\mathrm{c} \times \mathrm{x}\end{array}$ \\
\hline Globigerinita incrusta Arkers & $x \times \times \quad \times \times \times \times \times \times x \quad x \times \times \times$ \\
\hline Globoquadrina dehiscens praedehiscens Blow and Banner & $\mathrm{x}$ \\
\hline $\begin{array}{cl}\text { Globorotalia } & \text { kugleri Bolli } \\
\text { (Turborotalia) } & \text { obesa Bolli } \\
& \text { opima nana Bolli } \\
\text { peripheroronda Blow and Banner } \\
\text { pseudokugleri Blow } \\
\text { siakensis LeRoY }\end{array}$ & 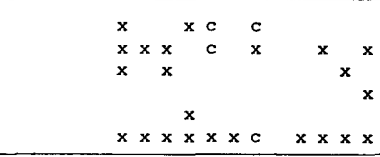 \\
\hline Globorotaloides suteri Bolli & $\times \times \times \times \times \times \times \times \times \times \times \times$ \\
\hline Cassigerinella chipolensis (Cushman and Ponton) & $x$ \\
\hline
\end{tabular}

Based on coexistance of $G$. (T.) kugleri and the species belonging to the genus Globigerinoides, the G. (T.) kugleri Zone is correlated with the Globigerinoides quadrilobatus primordius and Globorotalia (Turborotalia) kugleri Concurrent-Range Zone or Zone N. 4 of BLow (1969). In addition, as the upper part of this zone yields $C$. stainforthi and $G$. dehiscens dehiscens, this zone may

\section{Explanation of Plate 39}

Fig. 1. Globigerina gortanii BoRSETTI.

a, umbilical side; $b$, side view; $c$, spiral side. $\times 75$.

2. Globigerina angulisuturalis BoLLI.

a, umbilical side; $b$, side view; $c$, spiral side. $\times 180$.

3. Globorotalia opima opima BoLLI.

a, umbilical side; b, side view; c, spiral side. $\times 190$.

4. Globorotalia pseudokugleri BLow.

a, umbilical side; $b$, side view; $c$, spiral side. $\times 195$.

5. Globigerina ouachitaensis ciperoensis BoLLI.

a, umbilical side; b, side view; c, spiral side. $\times 125$.

6. Cassigerinella chipolensis (CUSHMAN and Ponton).

Side view. $\times 280$.

7. Globigerina ouachitaensis ouachitaensis HowE and WALLACE.

Umbilical side. $\times 205$.

8. Globigerina prasaepis BLow.

Umbilical side. $\times 120$.

9. Globoquadrina dehiscens praedehiscens BLOW and BANNER.

a, umbilical side; $b$, side view. $\times 95$. 


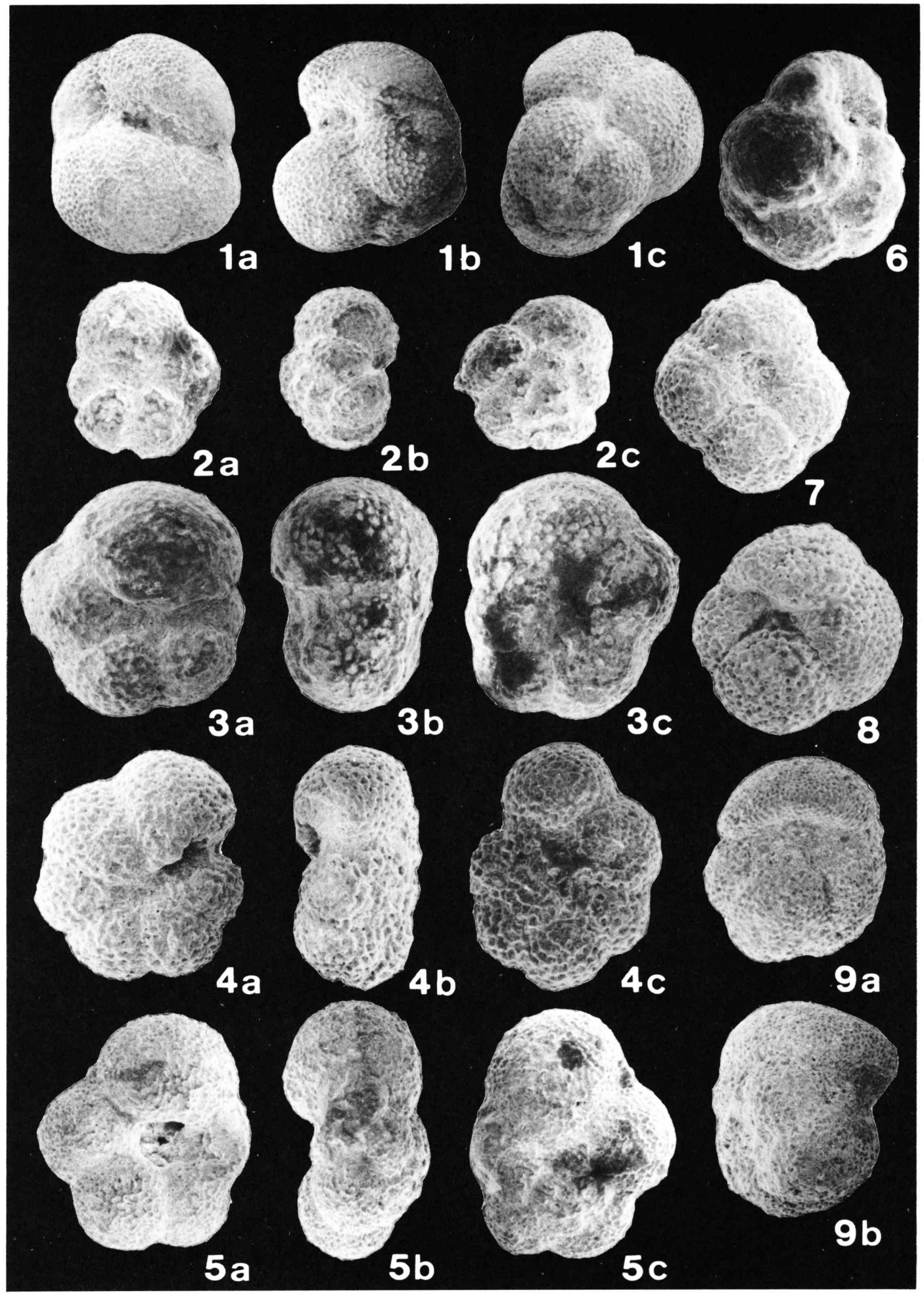

H. NisHi: Stratigraphy of Oligocene-Miocene Nichinan Group 


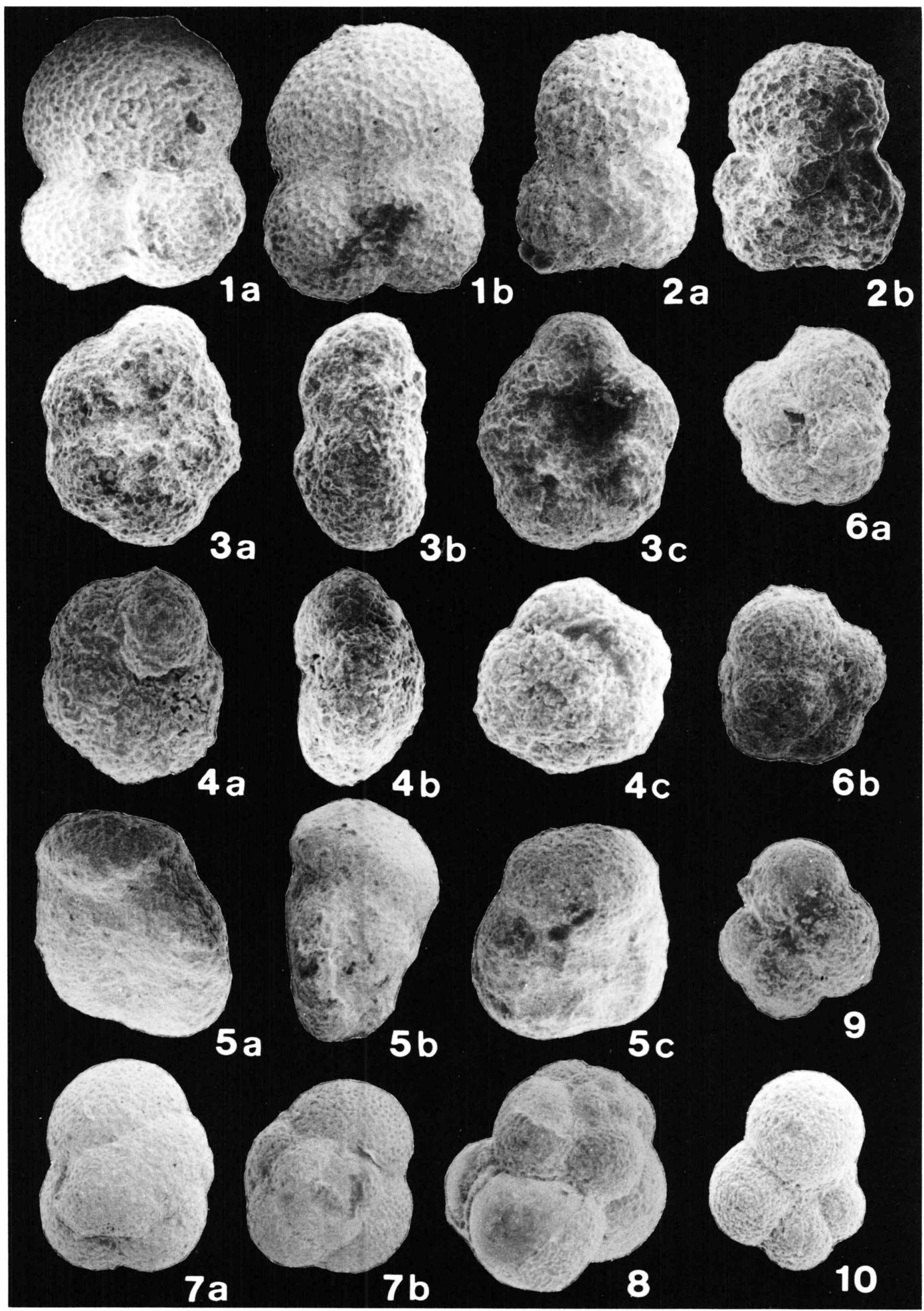

H. Nishi: Stratigraphy of Oligocene-Miocene Nichinan Group 
range up to the upper part of Zone N. 4.

On the bases of the above-mentioned results, the $G$. (T.) opima opima Zone, the G. angulisuturalis Zone, and the G. (T.) kugleri Zone of the Nichinan Group are referable to Late Oligocene, Latest Oligocene, and Earliest Miocene age, respectively.

\section{Oligocene-Miocene Boundary}

As stated above, the biostratigraphic boundary between N. 3 and N. 4 that is correlated with the Oligocene-Miocene boundary can be drawn in the middle part of the Takigahirayama Formation of the Nichinan Group. This is the first setting of the Oligocene-Miocene boundary in Japan.

The Oligocene-Miocene boundary has been defined by the first occurrence of the following species: (1) Globigerinoides (e.g. BLow, 1969; STAINForTH et al., 1975), (2) Globorotalia kugleri (e.g. BIoLzI, 1982), (3) Globoquadrina dehiscens (e.g. SRINIVASAN and KENNETT, 1983), (4) Globorotalia peripheroronda and Globoquadrina altispira (STAINFORTH and LAMB, 1981).

BLow (1969) demonstrated that the Oligocene-Miocene boundary can be placed at the level of the first appearance of Globigerinoides primordius and that $G$. (T.) kugleri first appears in the upper part of Zone N. 3. Many workers, however, indicated that Globigerinoides primordius first appears in late Oligocene rocks (Lamb and Stainforth, 1976; Seiglie, 1973). Stainforth and Lamb (1981) reported that small specimens of Globigerinoides primordius appear in and persist through the Globigerina ciperoensis Zone of late Oligocene age in two cores on the Atlantic continental slope and on the Florida shelf in the Gulf of Mexico. BIoLzI (1982) showed the correlation between planktonic foraminiferal and calcareous nannofossil zonations of DSDP Site 354 in the Equatorial

\section{Explanation of Plate 40}

Fig. 1. Globigerinoides quadrilobatus immaturus LERoY. a, umbilical side; $b$, spiral side. $\times 135$.

2. Globigerinoides quadrilobatus primordius BLoW and BANNER. a, spiral side; $b$, umbilical side. $\times 165$.

3. Globorotalia kugleri BoLLr. a, umbilical side; $b$, side view; c, spiral side. $\times 155$.

4. Globorotalia mendacis BLow. a, umbilical side; $b$, side view; $c$, spiral side. $\times 270$.

5. Globoquadrina dehiscens dehiscens (ChAPMan, PARR and Collins). $a$, umbilical side; $b$, side view; $c$, spiral side. $\times 75$.

6. Catapsydrax stainforthi BoLLI, LOEBLICH and TAPPAN. a, umbilical side; $b$, spiral side. $\times 125$.

7. Catapsydrax dissimilis (CUShMAN and Bermúdez). a, umbilical side; $b$, spiral side. $\times 60$.

8. Globigerina bradyi WIESNER. Side view. $\times 185$.

9. Globorotalia opima nana BoLLI. Umbilical side. $\times 230$.

10. Globorotalia obesa BoLLI. Umbilical side. $\times 180$. 
Atlantic, and placed the Oligocene-Miocene boundary at the level of first occurrence of G. kugleri. On the other hand, SRINVASAN and KenNETT (1983) emphasized the validity of the first appearance of $G$. dehiscens as a marker of the Oligocene-Miocene boundary on the basis of qualitative and quantitative study of Foraminifera from the cores of three DSDP sites $(289,208,206)$ in the South Pacific ranging from the equator to the temperate regions.

As for the Nichinan Group of the investigated area, the first occurrence of G. kugleri and G. primordius are almost contemporaneous, and this level demarcates the boundary between G. angulisuturalis Zone and G. kugleri Zone (Figs. 9 and 10). I, therefore, define the first occurrence of G. kugleri as the OligoceneMiocene boundary in this paper, as $G$. primordius tends to be present in late Oligocene sections of other regions as mentioned above. In the Nichinan Group, the first occurrence of $G$. dehiscens is almost contemporaneous with $C$. stainforthi, and is at the higher level than the boundary between the G. kugleri Zone and the G. angulisuturalis Zone, that is the Oligocene-Miocene boundary defined above. Accordingly, so far as the foraminiferal biostratigraphy is concerned, it is not appropriate to set the Oligocene-Miocene boundary at the level of the first appearance of $G$. dehiscens, because $C$. stainforthi is generally known to occur from the upper part of Zone N. 4 and also from higher levels.

Thus, in the Nichinan Group the Oligocene-Miocene boundary is placed on foraminiferal evidence between $G$. angulisuturalis Zone and G. kugleri Zone, in the upper part of the alternating beds (T-b) of the Lower Subformation of the Takigahirayama Formation (Figs. 6 and 10).

\section{Trends of Microfossils}

From the lithostratigraphic sequence, depositional facies and sedimentary structures, the Nichinan Group are comparable with those of submarine fan deposits, as noted before. Then, in what sort of paleobathymetric setting environment was this group deposited?

Paleobathymetric and paleoenvironmental interpretation of ancient sediments have been attempted by means of applying the knowledge on the ecology and systematic trends of microfauna, mainly of Foraminifera in terms of their geographic distribution and depth zonation (e.g. BANDY, 1953, 1961; INGLE, 1967, 1980). Moreover, on the basis of comparison of species composition and general morphologic trends of modern and ancient benthic Foraminifera, assignment of species to bathymetrically defined faunal groups representing inner shelf through lower bathyal zone are being accomplished (e.g. INGLE, 1967,1980 ). In addition, variations in the relative abundance of Foraminifera and Radiolaria with water depth are analysed (INGLE 1980; INGLE et al. 1980).

Fortunately, the Nichinan Group abundantly yields benthic and planktonic Foraminifera at many stratigraphic levels and Radiolaria at fairly many horizons, although these are interruption by thick sandstones within the sequence, and offers an oppotunity to analyse the paleobathymetry with the aids of the above-mentioned knowledge. In this paper, the following items were examined to know major vertical variations of Foraminifera and Radiolaria. 
(1) Percentages of Foraminifera and Radiolaria

(2) Percentages of Planktonic and Benethic Foraminifera

As for methods, each sample was put in a beaker and soaked in dilute $\mathrm{HF}$ ( $3 \%$ ) solution for one hour, and the residue was washed on a 250 mesh screen (60 micron openings). Then, all specimens of Foraminifera and Radiolaria in the residues were picked up, and their numbers were counted. Planktonic Foraminifera was specifically identified, and their percentages in each sample were calculated. Fig. 11 illustrates the result of examination on the above-mentioned items plotted in relation to the stratigraphic sequence of the Nichinan
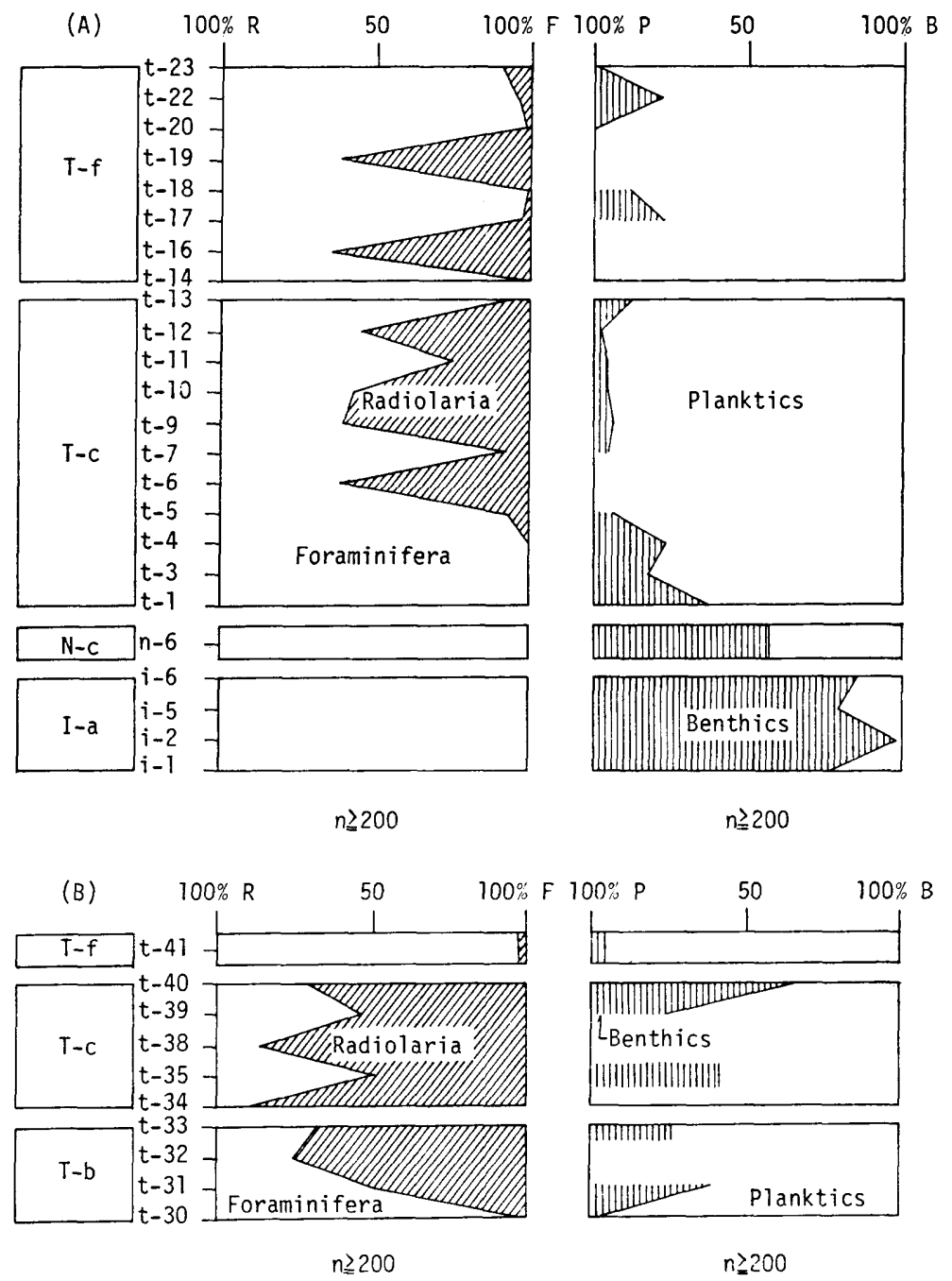

Fig. 11. Percentage of Foraminifera and Radiolaria and benthic and planktonic Foraminifera plotted against stratigraphic sequence. A. southern limb, B. overturned northern limb. I-a: Ichiki Formation, N-c: Nango Formation, $T-b$ to $f$ : Takigahirayama Formation. 
Group. This figure shows a general aspect of stratigraphic variations in the relative abundance of major foraminiferal groups and Radiolaria.

\section{(1) Percentages of Foraminifera and Radiolaria}

In the section of the southern limb (A in Fig. 11) of the Nango Syncline, occurrence of Radiolaria is rare in the samples from the Ichiki, Nango, and the lower part of the Lower Subformation of the Takigahirayama Formation, but become common above the level of t-5. Above this horizon, the percentage of Radiolaria increases and decreases one after another. In the mudstone of T-c and $T-f$, the percentage attains more than $50 \%$ in not a few samples ( $t-6, t-9$, $t-10, t-12, t-16$, and $t-19$ ). In the section of the northern overturned limb ( $B$ in Fig. 11), the percentage of Radiolaria increases above the level of $t-31$ to attain more than $50 \%$, and exhibits smaller fluctuation than in that of the southern limb, although it decreases in T-f.

(2) Percentages of planktonic and benthic Foraminifera

In the section of the southern limb (A in Fig. 11), the benthic Foraminifera reaches more than $75 \%$ in the Ichiki Formation, becomes approximately $50 \%$ in the Nango Formation, and gradually decreases to less than $25 \%$ at the levels above t-3 of the Takigahirayama Formation. In other words, planktonic Foraminifera are gradually increased in the Takigahirayam Formtion. While, in the section of overturned limb ( $B$ in Fig. 11), the percentage of benthic Foraminifera tends to repeatedily rise and fall while the range from approximately $10 \%$ to $60 \%$, although samples containing fossils were few.

Thus, the microfossils of the Nichinan Group show a fairly marked general trend in the increase of the relative abundance of planktonic Foraminifera and Radiolaria as stratigraphically followed upwards. This microfaunal trend well accords with the vertical lithologic changes of the group represented by the predominance of muddy facies in the upper part of the sequence and the upwardfining of sandstone beds. As mentioned above, this vertical lithofacies change probably reflects retrogradation of submarine-fan deposits from a middle fan to a lower fan or deepening of depositional environments. In a detailed view, however, there is marked vertical fluctuation of the relative abundance of Radiolaria in the Takigahirayama Formation. Whether this fluctuation has resulted from climatic or oceanographic changes or from the changes of water-mass properties cannot be revealed, because no distinct lithologic differences are recognized among the mudstone beds from which the microfossils were obtained. On the other side, the relative abundance of benthic Foraminifera at $t-31,-33,-35,-39$, and -40 in the section of the northern limb and t-17 (not shown in Fig. 11) and -22 in that of the southern limb may have been connected with the influx of shallow-water sediment transported by sediment gravity flows, because the mudstone of these localities commonly contains silty laminae less than $5 \mathrm{~mm}$ in thickness.

For estimating paleobathymetry of ancient sediments various methods have been attempted. Especially planktonic/benthic foraminiferal ratio has 
been demonstrated by many workers to be reliable, and knowledge on the depth distribution of Recent Foraminifera provide analogies useful for interpreting the paleobathymetry. In this connection, Grimsdale and MorkhovaN (1955) showed that the relative proportion of planktonic and benthic Foraminifera in Recent open ocean sediments of Gulf of Mexico almost steadily increases with water depth up to approximately $1000 \mathrm{~m}$ and keeps a high value nearly $90 \%$ in water depth more than that. In the quantitative analysis on faunal distribution of benthic Foraminifera in relation to water-mass properties under the water ranging from the outer shelf to abyssal zones in the Peru-Chile Trench area, INGLE et al. (1980) indicated that the percentage of planktonic Foraminifera in total foraminiferal population increases with depth up to about $2800 \mathrm{~m}$ and then decreases with the increase of Radiolaria, although in detail a fairly large extent of flctuation is recognized. They also showed that the relative abundance of Radiolaria to Foraminifera nearly steadily increases with depth and exceeds $40 \%$ in the depth more than $2000 \mathrm{~m}$.

In the Nichinan Group, the percentage of planktonic specimens in total foraminiferal population gradually increases upwards from the Ichiki Formation to the Takigahirayama Formation and reaches more than $75 \%$ in many samples. The relative proportion of Radiolaria to Foraminifera also increases in the Takigahirayama Formation and shows high value more than 50\% at many levels. From the comparison of these microfaunal trends in the Nichinan Group with the above-mentioned biofacies changes in water depth of Recent sediments, it is inferred that the Takigahirayama Formation was deposited in the depth more than $1000 \mathrm{~m}$ but not deeper than $3000 \mathrm{~m}$, because CCD in Late Oligocene to Miocene times is known to have been at depth 3000 to $3500 \mathrm{~m}$ (RAMSAY, 1977).

Although no detailed taxonomic study of the benthic Foraminifera has been made, one thing to be added is the common occurrence of Bathysiphon and Cyclamina from mudstones of all formations of the Nichinan Group. According to the study of Kitazato (1979), these genera are limited at water-depth larger than $1000 \mathrm{~m}$. From these faunal characteristics, it is concluded that the Nichinan Group is the deposit at depth ranging from 1000 to $3000 \mathrm{~m}$, that is, in the middle bathyal to the lower bathyal zone of INGLE's Recent benthic foraminiferal biofacies classification.

\section{Conclusions}

Results of the present study are summarized as follows:

(1) The Nichinan Group of the Nango area in the Nichinan Mountains, Kyushu, is lithologically divisible into three formations, the Ichiki, Nango, and Takigahirayama Formations in ascending order. It is characterized by cyclic lithofacies changes represented by coarsening- and thickening-upward sequences and fining- and thinning-upward ones, and its overall lithostratigraphy shows an major fining-upward sequence. This group is referred to as a submarine-fan deposits ranging from a middle to a lower fan.

(2) Paleontological investigations on the planktonic Foraminifera ob- 
tained from the group indicate that the $G$. (T.) opima opima, G. angulisuturalis, and $G$. (T.) kugleri Zones were discriminated. The Ichiki Formation and the lower part of the Nango Formation belong to the G. (T.) opima opima Zone, the upper part of the Nango Formation and the lower part of the Takigahirayama Formation to the $G$. angulisuturalis Zone, and the middle and upper parts of the Takigahirayama Formation to the G. (T.) kugleri Zone.

(3) These three zones correspond to P. 21, P. 22, and N. 4, which are designated as Late Oligocene, Latest Oligocene, and Earlist Miocene age, respectively.

(4) The microfauna of this group shows a distinct upward increase in the proportion of planktonic Foraminifera to benthic ones and Radiolaria to Foraminifera. From the comparison of relative abundance of planktonic Foraminifera and Radiolaria in the Nichinan Group with that of Recent open-ocean sediments, it is inferred that this group was deposited at depth between 1000 and $3000 \mathrm{~m}$.

\section{Acknowledgements}

This study was carried out under the direction of Prof. KAMEToshi KANMERA of Kyushu University. I am much indebted to him for his valuable instructions on the geology of the study area and his critical reading of the manuscript. Special thanks are due to Prof. Tsunemasa SaITo of Yamagata University, who gave me many helpful advice on the taxonomy of the planktonic Foraminifera. I am also grateful to Dr. KUNIo KAIHo of Yamagata University, who identified benthic Foraminifera.

This paper is dedicated to Professor Tsugio ShUto, who made a pioneering work on the stratigraphy of the Nichinan Group.

\section{References}

BANDY, O. L. (1953) : Ecology and paleoecology of some California foraminifera. Jour. Paleontology, 27, 161-203.

(1961): Distribution of foraminifera, radiolaria and diatoms in sediments of the Gulf of California Micropaleontology, 7, 1-26.

Brolzi, M. (1982) : The Oligocene/Miocene boundary in the equatorial Atlantic DSDP Site 354. Results of studies on planktonic foraminifera and calcareous nannofossils. Riv. Ital. Paleont., 88, (1), 113-132.

Blow, W. H. (1969): Late middle Eocene to Recent planktonic foraminiferal biostratigraphy. In Bronnimann, P. and Renz, H. H. (eds.), 1st Interna. Conf. Plankton. Microfossils, 1, 199-422, Brill Leiden.

INGLE, J. C. (1967): Foraminiferal biofacies and the Miocene-Pliocene boundary in southern California. Bull. Am. Paleontology, 52, 1-217.

(1980) : Cenozoic paleobathymetry and depositional history of selected sequences within the southern California continental borderland. Cushman Found. Spec. Publication 19, 163-195.

—_, and KeLLER, G., and KolpaCK, R. L. (1980): Benthic foraminiferal biofacies, sediments and water masses of the southern Peru-Chile Trench area, southeastern Pacific Ocean. Micropaleontology, 6, 345-371.

Grimsdale, T. and Markhoven, F. (1955): The ratio between pelagic and benthonic 
foraminifera as a means of estimating depth of deposition of sedimentary rocks. IV World Petrology Congress, Proceedings, Sect. I/D. Rept. 4, 473-491.

KANMERA, K. and SASAKI, M. (1977): Olistostrome in the Toi-Misaki area, the southernmost part of the Shimanto Terrane (in Japanese). Abs. 1977 Ann. Meet. Geol. Soc. Japan. 163.

—, SakaI, T., TsujI, T., and Nishi, H. (1983): Geology in the southern and eastern part of the Nichinan Mountains (in Japanese). Guide Book of Excursion. 1983 Ann. Meet. Geol. Soc. Japan, 23-36.

Kato, T., Nakagawa, H., Oda, N., Hasegawa, S., and Yasuda, N. (1984) : Stratigraphy and structure of the Nichinan Group (Preliminary report) (in Japanese). Biostratigraphy and International Correlation of the Palaeogene System in Japan, Yamagata University, 113-130.

Kitazato, H. (1979) : Marine paleobathymetry and paleontopography of the Hokuroku district during the time of Kuroko deposition, based on foraminiferal assemblagge. Mining Geol., 29, (4), 207-216.

Kuroda, H. and Matsumoto, T. (1942): Geological study of Southern Nichinan District, Kyushu. - (Preliminary report) - With Special Reference to the Geology around the Aburatsu City (in Japanese). Jour. Geol. Soc. Japan, 49, 255-256.

LAMB, J. L. and StAINFoRTh, R. M. (1976): Unreliability of Globigerinoides datum. Bull. Am. Assoc. Pet. Geol., 60, 1564-1569.

MutTI, E. and RICCI-LuCCHI, F. (1972): Le torbiditi dell 'Apennino settentrionale: introduzione all 'Apennino settentrionale: introduzione all' analizi di facies: Mem. Soc. Geol. Italy, 11, 161-199. English translation in International Geology Review, 1978, 20, (2), 125-166.

Nakagawa, H., Osozawa, S., Aita, Y. and Kato, T. (1983): Gravity tectonics of the Ryukyu Arc, southwestern Japan (in Japanese). In Spec. Publ. Commit. Nishinihon Branch Geol. Soc. Japan (ed.), Geologic Development of the Kyushu Island, $77-82$.

RAMSAY, A. T. S. (1977): Sedimentological clues to paleooceanology. In A. T. S. RAMSAY (ed.), Oceanic Micropaleontology, Academic Press, 2, 1371-1453.

SAKAI, T. and KANMERA, K. (1981): Stratigraphy of the Shimanto Terrane and tectono-stratigraphic setting of greenstones in the northern part of Miyazaki Prefecture, Kyushu (in Japanese). Sci. Rept., Dept. Geol., Kyushu Univ., 14, (1), 31-48.

-, Nishi, H., Saito, T., Nakaseko, K., and Nishimura, A. (1984) : Microfossil stratigraphy of the Paleogene System in Kyushu Shimanto Belt (in Japanese). Biostratigraphy and International Correlation of the Paleogene System in Japan, Yamagata University, 95-112.

Seiglie, G. A. (1973) : Revision of mid-Tertiary stratigraphy of southwestern Puerto Rico. Bull. Am. Ass. Pet. Geol., 57, 405-406.

Shuto, T. (1963): Geology of the Nichinan area with the special reference to the Takachiho disturbance (in Japanese). Sci. Rept., Dept. Geol., Kyushu Univ., 6, $135-166$.

SRINivasan, M. S. and KenNetT, J. P. (1983): The Oligocene-Miocene boundary in the South Pacific. Geol. Soc. Am. Bull., 94, 798-812.

Stainforth, R. M., Lamb, J. L., Leterbacher, H., Beard, J. H. and Jeffords, R. M. (1975): Cenozoic planktonic foraminiferal zonation and characteristics of index forms. Univ. Kansas, Paleont. Contr., Article 62, 1-425. and LAMB, J. L. (1981): An evaluation of planktonic foraminiferal zonation of the Oligocene. Univ. Kansas, Paleont. Contr., Paper 104, 1-34. 